\title{
Thermotectonic evolution of the Ukrainian Donbas Foldbelt revisited: new constraints from zircon and apatite fission track data
}

\author{
M. Danišík, *† R. F. Sachsenhofer, $\ddagger$ W. Frisch,* V. A. Privalov,§ E. A. Panova \\ C. Spiegel* $\|$ \\ * Institute of Geosciences, University of Tübingen, Tübingen, Germany \\ $\dagger$ John de Laeter Centre of Mass Spectrometry, Applied Geology, Curtin University of Technology, Perth, WA, Australia \\ $\ddagger$ Department of Applied Geosciences and Geophysics, University of Leoben, Leoben, Austria \\ $\S$ Department of Geology, Donetsk National Technical University, Donetsk, Ukraine \\ - UkrNIMI, National Academy of Sciences of Ukraine, Tchelyuskintsev str. 291, Donetsk, Ukraine \\ ||Department of Geosciences, University of Bremen, Bremen, Germany
}

\begin{abstract}
The Donbas Foldbelt (DF) is the compressionally deformed segment of a large Late Palaeozoic rift cross-cutting the southern part of the East European Craton and is traditionally described as a classic example of an inverted intracratonic rift basin. Proposed formational models are often controversial and numerous issues are still a matter of speculation, primarily due to the lack of absolute time constraints and insufficient knowledge of the thermal evolution. We investigate the low-temperature thermal history of the DF by means of zircon fission track and apatite fission track (AFT) thermochronology applied to Upper Carboniferous sediments. In all samples, the AFT chronometer was reset shortly after deposition in the Early Permian ( $\sim 275 \mathrm{Ma}$ ). Samples contained kinetically variable apatites that are sensitive to different temperatures and using statistic-based component analysis incorporating annealing characteristics of individual grains assessed by $D_{\mathrm{par}}$, we identified several distinct age populations, ranging from the Late Permian ( $\sim 265 \mathrm{Ma}$ ) to the Late Cretaceous ( $\sim 70 \mathrm{Ma}$ ). We could thus constrain the thermal history of the DF during a $\sim 200 \mathrm{Myr}$ long period following the thermal maximum. We found that earliest cooling of Permian and Permo-Triassic age is recorded on the basin margins whereas the central parts were residing in or slowly cooling through the apatite partial annealing zone during Jurassic and most of Cretaceous times, and then finally cooled to near-surface conditions latest around the Cretaceous/Palaeogene boundary. Our data show that Permian erosion was less significant and Mesozoic erosion more significant than generally assumed. Inversion and pop-up of the DF occurred in the Cretaceous and not in the Permian as previously thought. This is indicated by overall Cretaceous AFTages in the central parts of the basin.
\end{abstract}

\section{INTRODUCTION}

The Donbas Foldbelt (DF) is the compressionally deformed and inverted segment of a large Upper Palaeozoic intracratonic rift basin - the Pripyat-Dniepr-Donets Basin, which cross-cuts the Precambrian East European Craton in WNW-ESE direction (e.g. Stovba et al., 1996; Fig. la,b). It is located between the undeformed Dnieper-Donets Basin in the WNW and the deformed southern margin of the East European Craton (Karpinsky Swell) in the ESE. To the south, it is bordered by the Azov Massif (part of the Ukrainian Shield) and the Scythian Platform, to the north by the Voronezh Massif.

Correspondence: Martin Danišík, John de Laeter Center of Mass Spectrometry, Applied Geology, Curtin University of Technology, GPO Box U1987, Perth WA 6845, Australia. E-mail: M.Danisik@curtin.edu.au
There are several extraordinary features that make the DF an interesting study area. The basin represents a classical example of an inverted basin (Stovba \& Stephenson, 1999 ) as described by Cooper \& Williams (1989), i.e. an intracratonic extensional basin that was later compressionally deformed. It is one of the deepest rifts in Europe, filled with more than $20 \mathrm{~km}$ of (mainly) Late Palaeozoic sediments (e.g. Maystrenko et al., 2003; Fig. 1c). The DF contains one of the major coal fields in the world with proven reserves in the order of $60 \mathrm{Gt}$ (Privalov et al., 2004) and coal rank varying from subbituminous $\left(<0.6 \% R_{\mathrm{r}}\right)$ to anthracite stage ( $>2.5 \% R_{\mathrm{r}}$; Levenshtein et al., 1991; Fig. 2). It is characterized by a high potential for coal-bed methane projects (Privalov et al., 2004; Alsaab et al., 2008) and it hosts a variety of ore deposits (e.g. mercury, antimony, lead, zinc and gold mineralization; Nikolskiy et al., 1973; Lazarenko et al., 1975; Gavrish, 1989; de Boorder et al., 1996). 


\section{Danišik et al.}

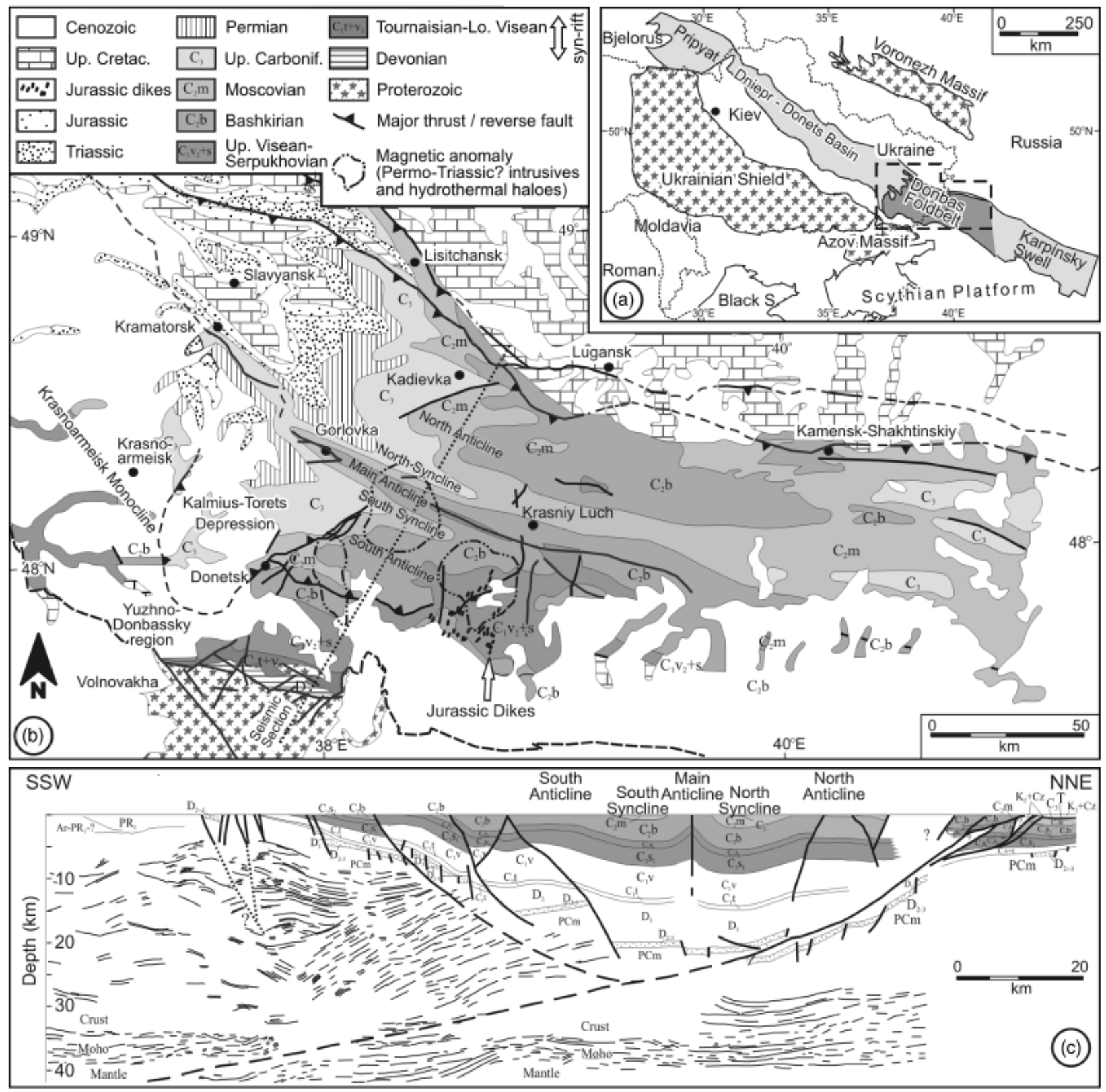

Fig. 1. (a) Location of the study area within the southern part of the Eastern European craton (after Stovba \& Stephenson, 1999). (b) Geological sketch map of the DF (modified after Popov, 1963). Location of Jurassic dikes and magnetic anomalies [interpreted as PermoTriassic(?) intrusions and their hydrothermal haloes] are shown after Aleksandrov et al. (1996). (c) Geological cross-section after Maystrenko et al. (2003).

In the past decade, the DF became a target of extensive geophysical and geological research. The subsurface structure of the basin was investigated using seismic profiles and boreholes (Chekunov et al., 1993; Ilchenko, 1996; DOBREfraction'99 Working Group, 2003; Maystrenko et al., 2003). In addition, the structural, tectonic and thermal evolution, basin inversion, and timing of magmatic activity were investigated by means of structural data, numerical modelling, vitrinite reflectance (VR) and radiometric dating (Privalov, 1998; Sachsenhofer et al., 2002; Saintot et al., 2003a, b; Alexandre et al., 2004; Spiegel et al., 2004). Consequently, significant progress has been achieved in the understanding of the geodynamic evolution of the DF and several models have been proposed by different work- ing groups. However, due to lack of absolute time constraints and insufficient understanding of the thermal evolution, the proposed models are often controversial and in fact, there are still numerous issues that are a matter of speculation (cf. Stovba \& Stephenson, 1999; Stephenson et al., 2001). These include identification and quantification of burial and exhumation events, the age of major structures, and the age of basin inversion.

In this study, we aim to tackle these issues by applying low-temperature thermochronological dating methods [apatite and zircon fission track (AFT and ZFT, respectively) dating] to Upper Carboniferous sedimentary samples. Although in all samples the AFT chronometer was reset shortly after deposition in the Early Permian 


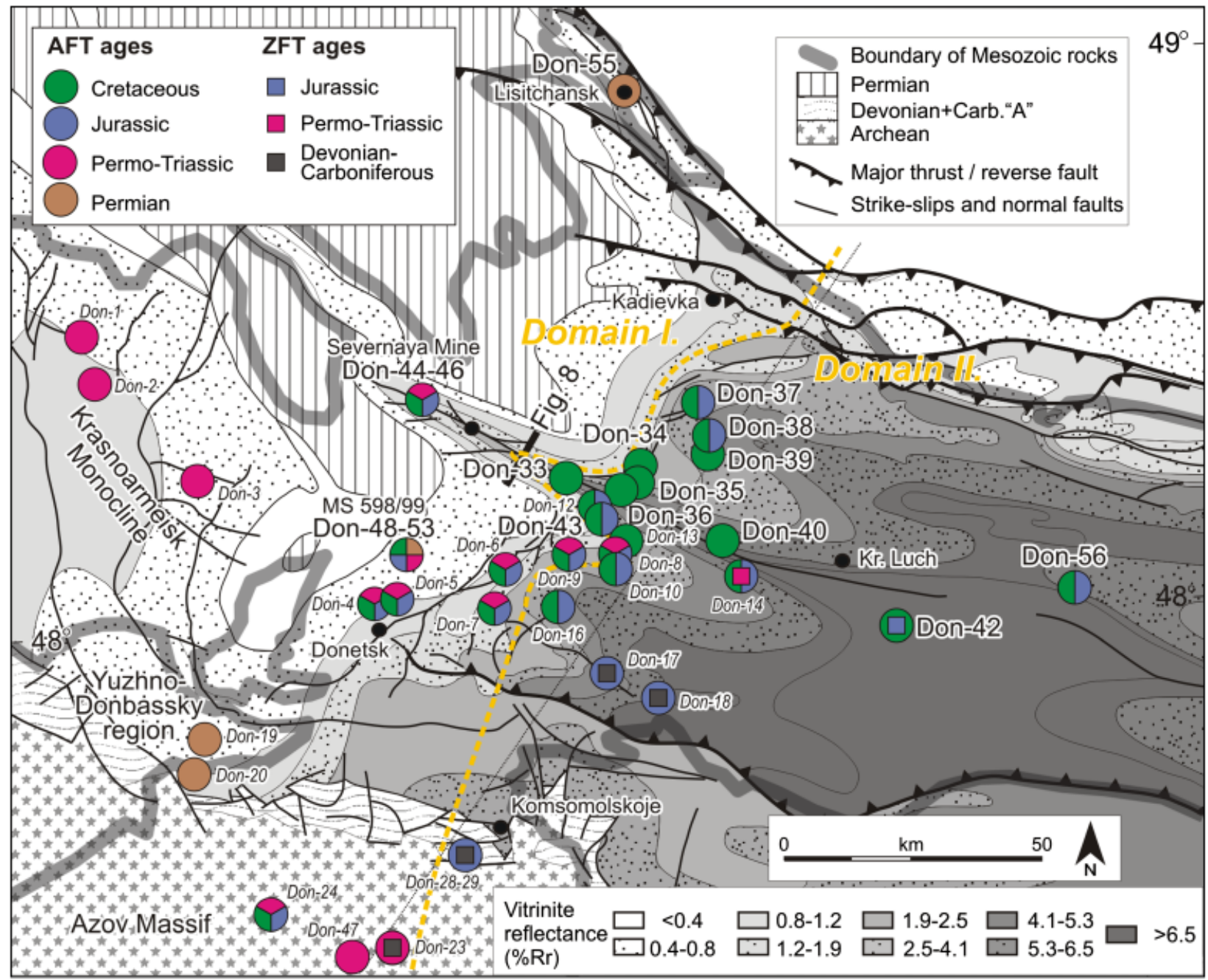

Fig. 2. Map showing coalification pattern at the top of the Carboniferous sequence (after Levenshtein et al., 1991), distribution of Permian and Mesozoic cover (compiled from Levenshtein et al., 1991; Kuťko, 1995; Kolosovska et al., 2007), sample location and fission track (FT) age populations expressed in the form of colour-coded circles [apatite fission track (AFT) ages] and squares [zircon fission track (ZFT) ages]. Samples measured in this study are written in normal font, samples from Spiegel et al. (2004) and Danišík et al. (2008) in italic font. Subdivision into two domains is explained in 'Timing and amount of erosion'.

( $\sim 275 \mathrm{Ma}$ ), we took advantage of the fact that samples contained kinetically variable apatites, which are sensitive to different temperatures. Using statistic-based component analysis, incorporating physical properties of individual grains, we identified several distinct age populations, ranging from the Late Permian $(\sim 265 \mathrm{Ma})$ to the Late Cretaceous $(\sim 70 \mathrm{Ma})$. We could thus constrain the thermal history of the DF during a $\sim 200 \mathrm{Myr}$ period following the thermal maximum and revise proposed interpretations and models.

\section{GEOLOGICAL SETTING}

\section{Basin fill and structure}

The WNW-ESE-striking Pripyat-Dniepr-Donets Basin is more than $650 \mathrm{~km}$ long, up to $180 \mathrm{~km}$ wide and contains up to $25 \mathrm{~km}$ of sediments underlain by Precambrian basement of the Ukrainian shield (Fig. 1). The Moho depth be- neath the DF is at $40 \mathrm{~km}$ as revealed by refraction (DOBREfraction'99 Working Group, 2003) and reflection seismic profiles (Maystrenko et al., 2003).

In general, the thickness of sedimentary fill increases from the basin margins to the centre. The Palaeozoic sequence starts with a Middle/Upper Devonian to Lower Carboniferous (Lower Visean) succession comprising syn-rift volcanic and intrusive rocks, carbonates and continental clastic and volcaniclastic sediments (McCann et al., 2003). The total thickness of the syn-rift succession as exposed along the southern margin of the DF is $\sim 750 \mathrm{~m}$ but in the central part of the basin it may be up to $5 \mathrm{~km}$ (Garkalenko et al., 1971; Borodulin, 1974; Eisenverg et al., 1975; Lyashkevich, 1987; Stovba \& Stephenson, 1999). The post-rift Carboniferous (Upper Visean to Upper Carboniferous) succession consists mostly of shallow-marine and continental sediments interbedded with $c a$. 130 workable coal seams. Total thickness of the post-rift sequence is around $14 \mathrm{~km}$ (Stovba \& Stephenson, 1999). This unusual thickness is partially the result of tectonic reactivations 
(Stephenson et al., 2006). Permian (Asselian-Lower Sakmarian) sedimentary rocks are preserved only along the western and northern (E of Kamensk-Shakhtinskiy) margins of the DF. This succession is up to $2.5 \mathrm{~km}$ thick and dominated by shallow-marine and coastal sediments represented by sand-shale series with sparse interbeds of limestone, coal and thick layers of evaporite (Nesterenko, 1978). Occurrences of Early Permian rift-related magmatic rocks were described from the southwestern part of the DF (Alexandre et al., 2004).

Almost no Mesozoic sedimentary rocks are preserved within the DF, but they occur on the surrounding platforms and along the NWmargin of the DFand its transition to the adjacent Dniepr-Donets Basin. The Mesozoic sedimentary succession is represented by marine and continental sediments (Eisenverg, 1988), and consists of Triassic (up to $150-200 \mathrm{~m}$ thick), Jurassic, (500 $\mathrm{m}$ thick) and Upper Cretaceous $(600 \mathrm{~m}$ thick) sequences that are separated by angular unconformities (Konashov, 1980; Eisenverg, 1988). There are also important occurrences of Mesozoic magmatic rocks (andesites, trachyandesites, lamprophyres, dolerites) that can be found in the southwestern part of the DF (Chekunov \& Naumenko, 1982; Alexandre et al., 2004). Alexandre et al. (2004) dated extrusive and intrusive samples from surface outcrops (Ar-Ar data on amphibole, biotite and plagioclase) and defined two periods of magmatic activity in the DF during Mesozoic times - Middle to Late Triassic and Middle (?) to Late Jurassic. Upper Jurassic lamprophyre dikes are found east of Donetsk in a northerly striking belt up to $20 \mathrm{~km}$ wide. Further, large hidden intrusions with hydrothermal haloes in the southwestern part of the DF (east of Donetsk) were reported by Aleksandrov et al. (1996), based on magnetic data and field observations. The age of these intrusions was not radiometrically determined, but the authors relate them to the formation of epigenetic ore deposits in the Donets Basin and advocate for a Permian/ Triassic? age (Nikolskiy et al., 1973; de Boorder et al., 1996).

Eocene to Upper Miocene rocks are comprised of sands, clays and marls, the thickness of which usually remains below $200 \mathrm{~m}$ but locally reaches up to $400 \mathrm{~m}$ (Eisenverg, 1988). They are primarily preserved in the marginal parts of the basin where they unconformably overlie Maastrichtian and older rocks (Eisenverg, 1988).

The central structure of the basin is dominated by WNW-ESE-striking anticlines and synclines (Fig. 1b). Minor normal faults and rotated fault blocks prevail along the southern margin whereas thrusts are found along the northern margin of the basin (Bogdanov et al., 1947; Ustinovskiy, 1955). The largest and most prominent structure is a single, basin-parallel, almost symmetric fold with steeply dipping limbs $\left(60-80^{\circ}\right)$, called the Main (or Gorlovka) Anticline (Fig. 1c; Maidanovich \& Radzivill, 1984; Belichenko et al., 1999; Privalov et al., 2000). The Main Anticline (MA) is bounded by gentle synclines and anticlines (North and South Syncline; North and South Anticline; Fig. 1). The main structures towards the west of the DF are the Kalmius-Torets Depression and the Krasnoarmeisk
Monocline. The eastern margin of the Kalmius-Torets Depression is bounded by a set of NE-trending faults, the Donetsk-Kadievka fault zone.

\section{Evolution}

In the following sections, we briefly review the thermotectonic evolution of the study area and highlight problematic issues.

\section{Pre- and syn-rift phase}

Crustal extension and formation of the Pripyat-DnieprDonets rift basin commenced in the Middle Devonian and developed in several stages (Stephenson et al., 1993, 2006; Kusznir et al., 1996; Stovba \& Stephenson, 1999). The major rifting phases occurred in Late Devonian times and after a period of tectonic quiescence in the Visean (Saintot et al., 2003b). Active rifting was accompanied by intensive volcanic activity, probably related to a mantle-plume (Wilson \& Lyashkevich, 1996; Stephenson et al., 2006), resulting in emplacement of extrusive rocks and dikes.

\section{Post-Rift phase}

Major post-rift subsidence occurred in Carboniferous to Early Permian (Sakmarian) times, when an up to $14-\mathrm{km}-$ thick coal-bearing succession was deposited. Maximum burial in the central basin occurred during Sakmarian times ( $275 \mathrm{Ma}$; e.g. Sachsenhofer et al., 2002; Izart et al., 2003).

In the late Early Permian, the DF, especially its southern margin, was uplifted and eroded as reflected by a basinwide unconformity. The total amount of erosion may be up to $12 \mathrm{~km}$ as by maturity data and missing stratigraphy (e.g. Nagorny \& Nagorny, 1976; Stovba \& Stephenson, 1999). It is assumed that post-Permian erosion was minor (e.g. Sachsenhofer et al., 2002), although its magnitude is in fact unconstrained. The mechanisms of Permian erosion are discussed controversially. Several authors assigned erosion, basin inversion and formation of compressional structures to a compressive palaeostress field related to the Late Palaeozoic Caucasus/Uralian Variscan orogeny (e.g. Popov, 1936, 1939, 1963; Gavrish, 1989; Milanovsky, 1992; Privalov, 1998). In contrast, Stovba \& Stephenson (1999) and Saintot et al. (2003a, b) argued that the palaeostress field in the DF during Early Permian time was transtensive, therefore the basin inversion and development of compressional structures must have occurred later. Nevertheless, these authors speculate that the earliest set of folds (MA, synclines and anticlines south and north of it) could indeed have developed in the Permian in conjunction with salt movements (Stovba \& Stephenson, 1999; Saintot et al., 2003a, b).

As indicated by FTand VR data, the rocks in the DF attained their thermal maximum either during maximum burial or at the Permo-Triassic boundary ( $\sim 250 \mathrm{Ma})$, when magmatic activity probably caused maximum heat flow (Aleksandrov et al., 1996; Sachsenhofer et al., 2002; 
Table 1. Zircon fission track data*

\begin{tabular}{lllllllllllll}
\hline Code & Petrography & Stratigraphy & $N$ & $\rho_{\mathrm{S}}$ & $N_{\mathrm{s}}$ & $\rho_{\mathrm{I}}$ & $N_{\mathrm{i}}$ & $\rho_{\mathrm{D}}$ & $N_{\mathrm{d}}$ & $P\left(\chi^{2}\right)(\%)$ & $\operatorname{Age}(\mathrm{Ma})$ & $\pm 1 \sigma(\mathrm{Ma})$ \\
\hline Don-42 & Sandstone & Bashkirian $(\sim 318 \mathrm{Ma})$ & 25 & 270.362 & 1429 & 75.300 & 398 & 7.251 & 2801 & $>95$ & 159 & 10 \\
\hline
\end{tabular}

$* N$, number of dated zircon crystals; $\rho_{\mathrm{S}}\left(\rho_{\mathrm{I}}\right)$, spontaneous (induced) track densities $\left(\times 10^{5}\right.$ tracks cm $\left.^{-2}\right) ; N_{\mathrm{s}}\left(N_{i}\right)$, number of counted spontaneous (induced) tracks; $\rho_{\mathrm{D}}$, dosimeter track density $\left(\times 10^{5}\right.$ tracks $\left.\mathrm{cm}^{-2}\right) ; N_{\mathrm{d}}$, number of tracks counted on dosimeter; $P\left(\chi^{2}\right)$, probability obtaining $\chi^{2}$ value for $n$ degree of freedom (where $n=$ No. of crystals -1 ); Age $\pm 1 \sigma-$ central age \pm 1 standard error (Galbraith \& Laslett, 1993). Ages were calculated using $\zeta$ calibration method (Hurford \& Green, 1983), glass dosimeter $\mathrm{CN}-5$, and $\zeta$ value of $123.6 \pm 2.1 \mathrm{year}^{-2}$.

Spiegel et al., 2004). According to Saintot et al. (2006) both, uplift and Permo-Triassic magmatism might be related to slab break-off. The Permo-Triassic thermal event had regional character and was detected in several parts of the DF (see Fig. 2 in Spiegel et al., 2004) as well as in the Krasnoarmeisk Monocline and the Azov Massif in the south (Sachsenhofer et al., 2002; Spiegel et al., 2004; Danišík et al., 2008).

Owing to lack of geological constraints, the MesozoicCainozoic thermotectonic evolution of the DF is poorly constrained. It is known that at least the southwestern part of the DF experienced two phases of magmatic activity - in the Middle to Late Triassic and (Middle?) to Late Jurassic (Alexandre et al., 2004). The Jurassic AFTages obtained by Spiegel et al. (2004) were ascribed to elevated heat flow related to the Jurassic magmatic activity which reheated the samples to $90-100^{\circ} \mathrm{C}$ as inferred from modelled cooling paths. Furthermore, Spiegel et al. (2004) concluded that the samples cooled below $\sim 60{ }^{\circ} \mathrm{C}$ between 115 and $84 \mathrm{Ma}$.

During the Mesozoic-Cainozoic period, several compressional events affected the DF: at Triassic/Jurassic boundary (also known as Cimmerian phase), in the Early Cretaceous and at Cretaceous/Palaeocene boundary, the latter being the most significant (e.g. Popov, 1936, 1939, 1963; Stepanov, 1937; Belokon, 1971, 1975; Pogrebnov, 1971; Milanovsky, 1987; Privalov, 1998; Saintot et al., 2003a,b, 2006). These events, however, had little effect on the thermal evolution of the area (Spiegel et al., 2004). Several authors (e.g. Stovba \& Stephenson, 1999; Saintot et al., $2003 \mathrm{a}, \mathrm{b}$ ) argued that inversion and development of compressional structures in the DF was related mainly to deformation phase at the Triassic/Jurassic and especially Cretaceous/Palaeocene boundaries.

At present, the DF is experiencing a period of erosion. Temperature measurements in deep mines and exploration wells indicate present-day geothermal gradients and heat flows in the order of $30^{\circ} \mathrm{C} \mathrm{km}^{-1}$ and $56 \mathrm{mWm}^{-2}$, respectively (Gordienko et al., 1999; Stephenson et al., 2001; Sachsenhofer et al., 2002).

\section{SAMPLES AND METHODS}

For this study, 20 samples were collected in different structural positions from surface outcrops, boreholes and coal mines at depths of up to $1220 \mathrm{~m}$ below surface (see Fig. 2 for location of samples). Sampled lithologies include mostly sandstones and conglomerates of Bashkirian, Moscovian and Kasimovian age (Tables 1, 2 and Table SX1).
Eleven samples represent a profile following the MA along strike. Samples Don-44-46 are from the Severnaya mine located in the axial zone and the northern limb of the westernmost MA. Samples Don-33-36, Don-40 and Don-43 represent the central MA including the adjacent South (Don-43) and North Synclines (Don-36). Don-42 is from the stratigraphic deepest horizon exposed along the MA, whereas Don-56 is from the North Syncline in the centre of the DF.

Additional samples represent the eastern margin of the Kalmius-Torets Depression (borehole MS 598/99: Don48 to Don-53), the North Anticline (outcrop samples Don-37-39) and the northern basin margin near Lisitchansk (borehole B-4933: Don-55).

The western locations (borehole MS 598/99, Severnaya mine, Lisitchansk) are characterized by low thermal maturity $\left(<1.0 \% R_{\mathrm{r}}\right)$, whereas all other locations are characterized by high to very high maturity $\left(2.5\right.$ to $>6.5 \% R_{\mathrm{r}}$; Fig. 2$)$.

The fission track dating method is based on retention of damage trails (fission tracks) continuously produced by spontaneous fission of ${ }^{238} \mathrm{U}$ in U-bearing minerals such as apatite or zircon (Wagner, 1968). Fission tracks shorten (anneal) primarily in response to temperature and time and thereby act as a form of time recording thermometer (e.g. Gleadow et al., 1986a, b). The temperature interval of fission track shortening is called partial annealing zone (PAZ; e.g. Gleadow et al., 1986a, b). For zircon the PAZ is usually reported to range approximately from 190 to $380{ }^{\circ} \mathrm{C}$ (e.g. Tagami \& Shimada, 1996; Brandon et al., 1998; Rahn et al., 2004; Tagami, 2005). For the interpretation of ZFT data generated in this study, we adopt an effective closure temperature of $240 \pm 30^{\circ} \mathrm{C}$ (Hurford, 1986; Brandon et al., 1998). Fission track annealing kinetics in apatites is controlled by temperature, time and also by the bulk chemical composition (particularly the $\mathrm{Cl} / \mathrm{F}$ ratio; e.g. Green et al., 1986). In general, fluorine rich apatites are less resistant to annealing than chlorine rich apatites, and the temperature range of the PAZ can vary from $\sim 50-110$ to $\sim 70-140^{\circ} \mathrm{C}$, respectively (Gleadow et al., 1983, 1986a, b; Green et al., 1989; Wagner \& Van den haute, 1992; Carlson et al., 1999; Barbarand et al., 2003). Therefore, in the ideal case, the annealing properties of each apatite grain analysed by the fission track methods should be determined in order to properly reconstruct the thermal history of the samples. This can be done either by measuring the chlorine content (Green et al., 1989) or by measuring diameters of etch-pits of fission tracks on $c$-axis parallel surfaces in apatite grains (so called $D_{\text {par }}$ values; Burtner et al., 1994; Barbarand et al., 2003). 


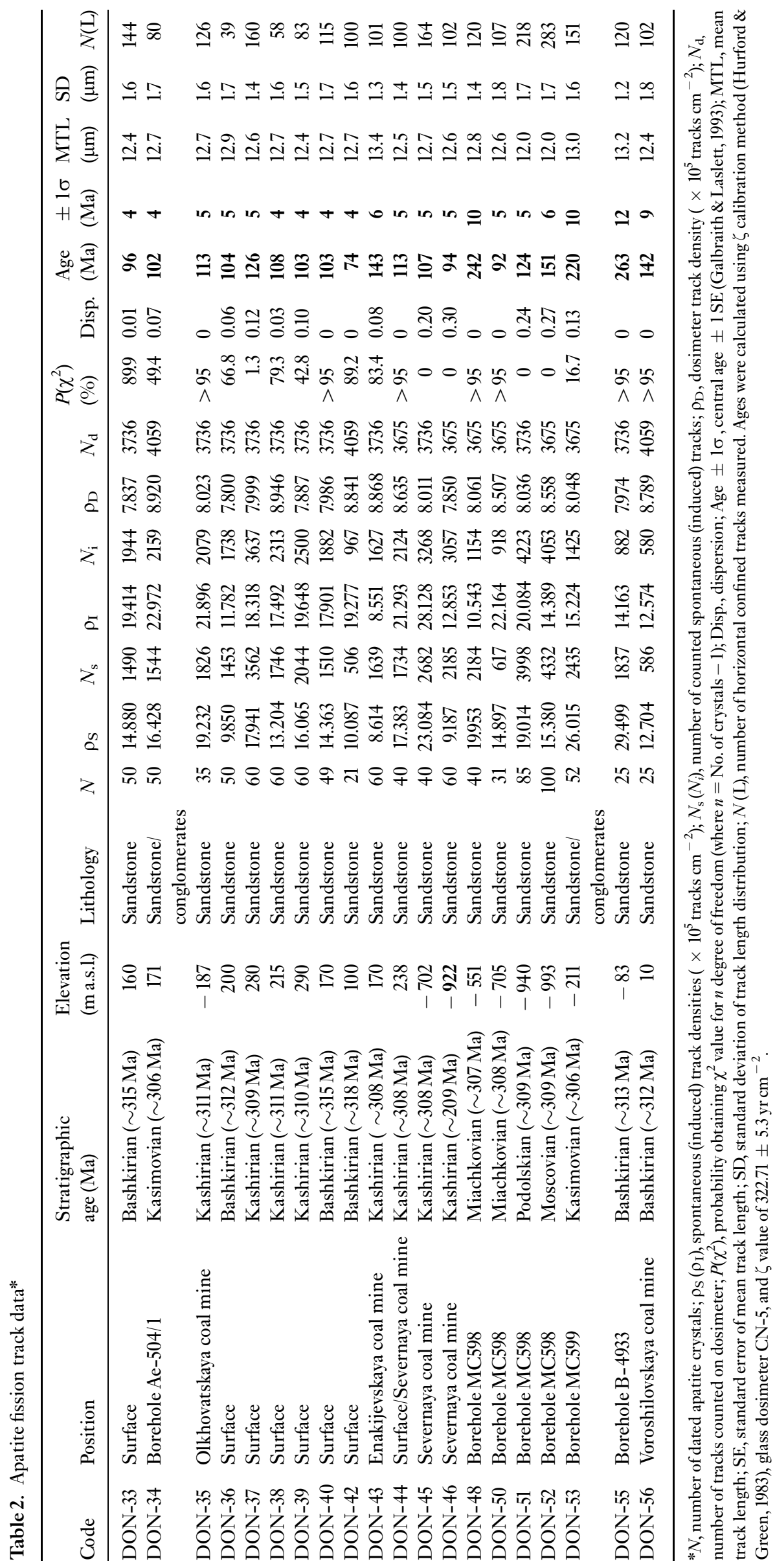


Sample preparation and FTanalysis followed the procedure outlined by Danišík et al. (2007). We used the external detector method (Gleadow, 1981) and the $\zeta$ age calibration approach (Hurford \& Green, 1983) to determine the FT age. Spontaneous tracks in apatites were revealed by etching with $5.5 \mathrm{M} \mathrm{HNO}_{3}$ solution for $20 \mathrm{~s}$ at $21^{\circ} \mathrm{C}$ (Donelick $e t$ al., 1999) whereas zircons were etched in a eutectic mixture of $\mathrm{KOH}$ and $\mathrm{NaOH}$ at $215^{\circ} \mathrm{C}$ for $7 \mathrm{~h}$ (Zaun \& Wagner, 1985). Samples were analysed with a Zeiss Axioskop 2 microscope (Carl Zeiss, Göttingen, Germany) equipped with a digitizing tablet and drawing tube, and controlled by the computer program FT Stage version 3.11 (Dumitru, 1993). Tracks in apatites and mica detectors were counted with $\times 1250$ magnification using a dry objective whereas tracks in zircons were counted under the same conditions but using an oil objective (Cargille oil type B, $n=1.515$ ).

Depending on the quality of the mounts, up to 100 grains per sample were analysed for age determination. FT ages were calculated with the program TrackKey version 4.2g (Dunkl, 2002). In each dated crystal, we measured the length of horizontal confined tracks and $D_{\text {par }}$ values to assess the kinetic properties of the grains. Because the track length data were not used for thermal history inversion, there was no requirement to normalize the confined track lengths in apatite for crystallographic angle and the $C$-axis projection (e.g. Donelick et al., 1999; Ketcham et al., 2007a, b) was not applied. Since the $D_{\text {par }}$ values are operator- and etchant-dependent (Sobel et al., 2004), three samples with pronounced kinetic variability indicated by $D_{\text {par }}$ were analysed with a JEOL Superprobe (JXA 8900 RL) electron microprobe (JEOL Inc., Peabody, MA, USA) in order to determine the $\mathrm{Cl}$ contents. We found good correlation between the $\mathrm{Cl}$ contents and $D_{\text {par }}$ values (Fig. 3), which justifies the usage of the latter as a proxy to assess the kinetic properties of the dated grains.

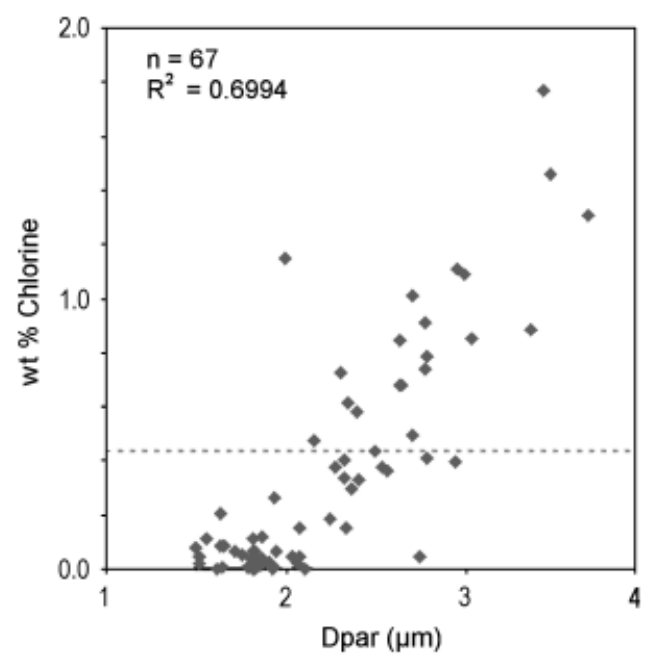

Fig. 3. $D_{\text {par }}$ values of randomly selected apatites plotted against their $\mathrm{Cl}$ content showing a fairly good correlation (correlation coefficient - 0.6994). The dashed line refers to the $\mathrm{Cl}$ content of Durango apatite ( $0.43 \mathrm{wt} . \%)$.
Several samples contain kinetically diverse apatites and yielded complex single-grain age spectra with high dispersion. In such cases, the reported central FT age is not representative and one has to identify individual age components within a sample. To do this, we first characterized and categorized dated grains according to the $D_{\text {par }}$ values, habitus, colour and surface properties (e.g. presence of inclusions, cracks, dislocations, impurities, etc.). We found that $D_{\text {par }}$ best correlated with single grain ages (see 'AFT data') and, as a first approximation, we defined age populations based on this parameter. This approach was particularly useful for identifying oldest age populations with

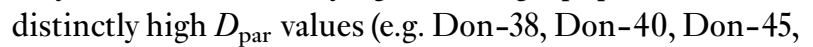
Don-51), but was less successful for grains with comparable $D_{\text {par }}$ (e.g. Don-36, Don-37, Don-53). Thus, as a second approximation, we used the PopShare software (Dunkl \& Székely, 2003; http://www.sediment.uni-goettingen.de/ staff/dunkl/software) for final component analysis. This software allows the analyst to resolve components in a mixture of data using the Simplex algorithm for the best-fit search (Dantzig, 1998). We first manually defined the age component corresponding to the oldest age population as defined according to $D_{\text {par }}$. Then we attempted to manually identify 1-2 age populations in the rest of data by fitting peaks over distinct groupings in age spectrum plots, trying to find the best solution with minimal root mean square value for goodness of fit. The optimality of the manually achieved solution was tested by the Simplex algorithm (500 iterations). Multiple trials per sample were performed and, where more than one statistically justified solution was found, the solution with lower number of age populations was chosen for interpretation in order not to overinterpret the data. For instance, a statistically valid solution with two overlapping age populations was found for sample Don-39, however, one age population solution with equally good statistic parameters was preferred.

\section{ANALYTICAL RESULTS}

\section{ZFT data}

In this study, a ZFTage was measured on one sample only (Don-42), taken from the crest of the MA in the lowest structural position (Table 1, Fig. 2). The sample passed the $\chi^{2}$-test at the $95 \%$ confidence interval and is thus interpreted to represent one age population. The measured ZFT age of $157 \pm 10 \mathrm{Ma}$ is younger than the depositional age $(\sim 318 \mathrm{Ma})$, indicating that the sample was heated to temperatures above $\sim 240{ }^{\circ} \mathrm{C}$ after deposition.

\section{AFT data}

The results of AFTanalyses are listed in Table 2. All AFT ages are younger than the depositional ages (Table 2), indicating that all samples experienced temperatures high enough to reset the FT chronometer in apatites. Nine samples revealed relatively narrow age spectra with one age population; however, most of the samples revealed complex single grain age distributions with broad scatter 

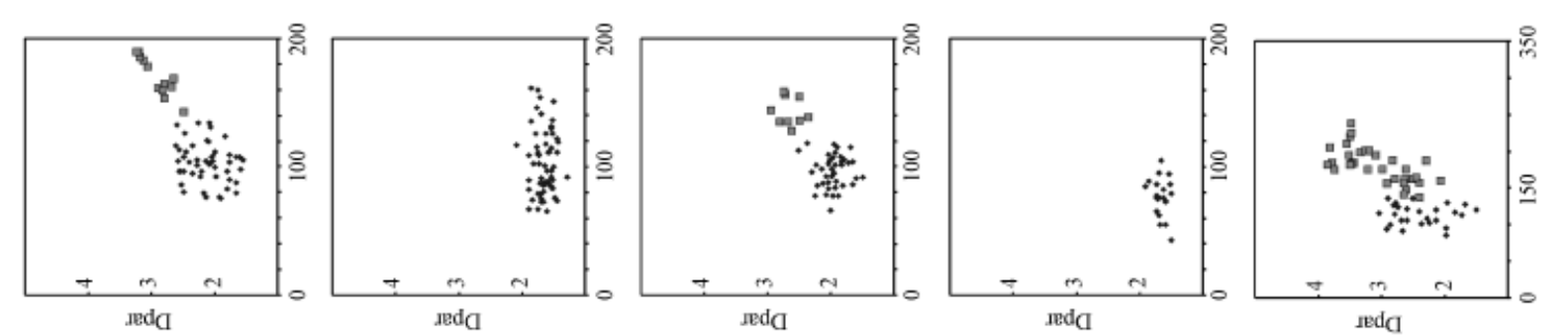

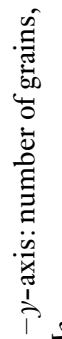
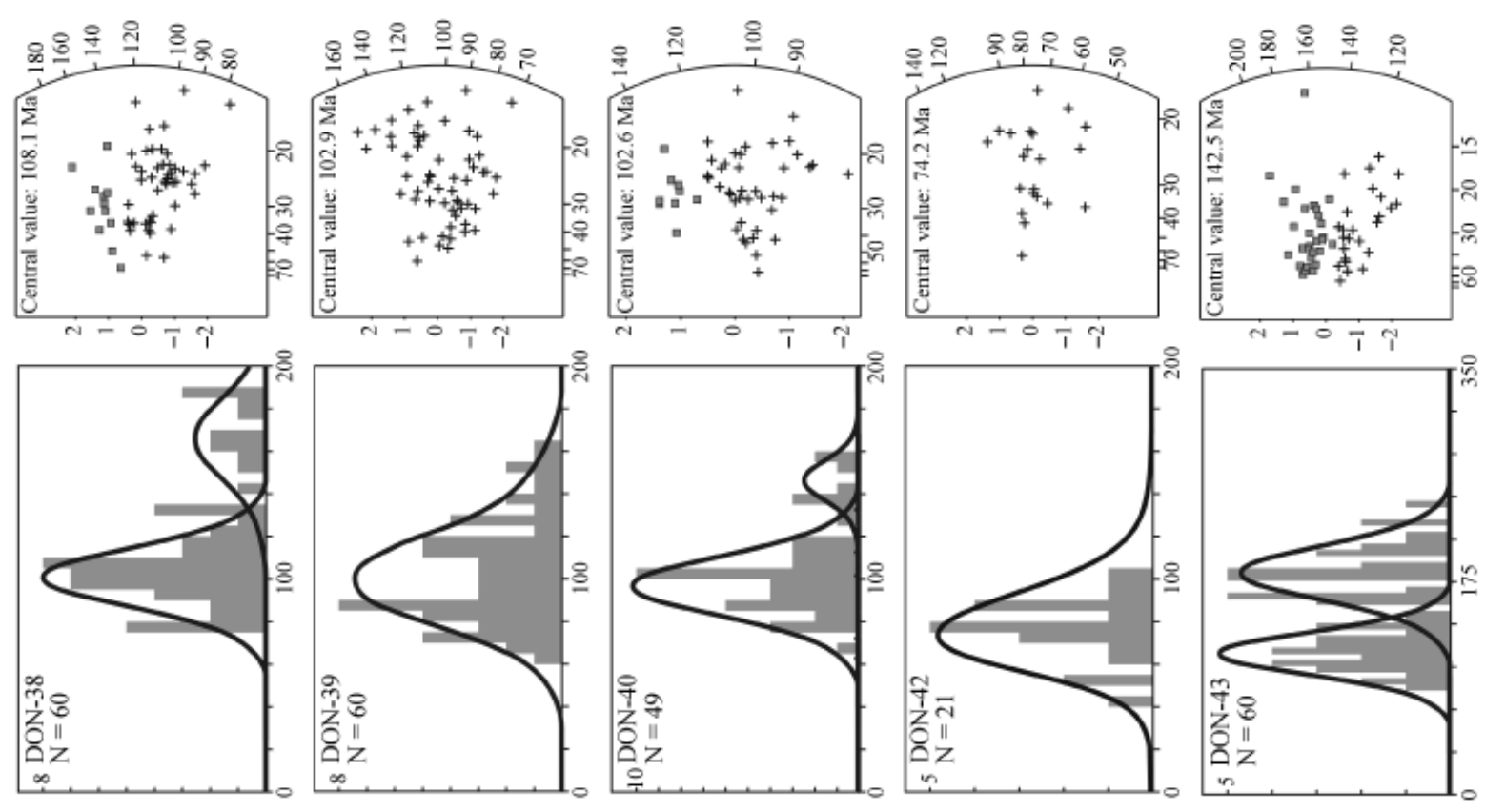

至
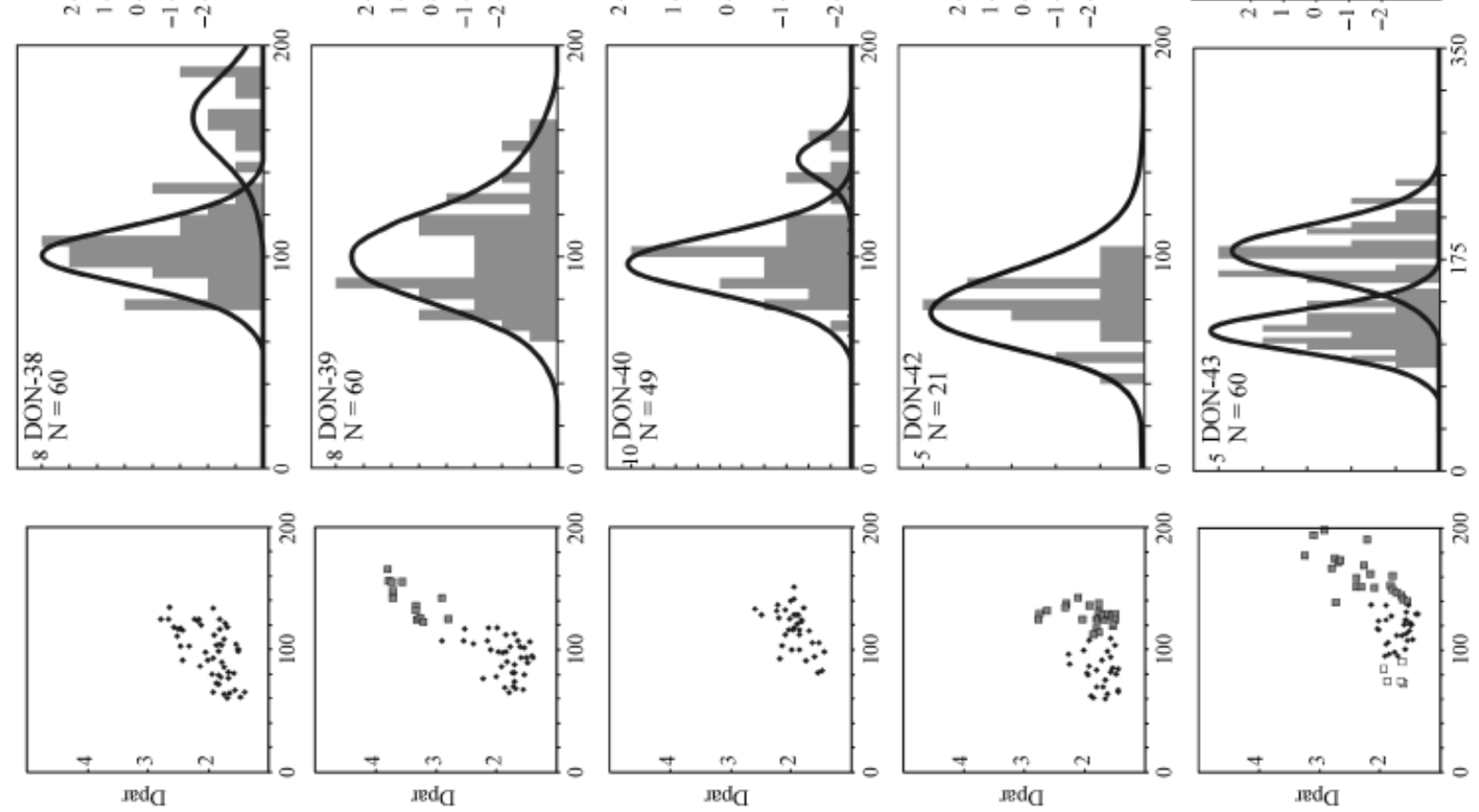

0
0
0
0
0
0
0
0
0
0
0
0
0
0
0
0
0
0
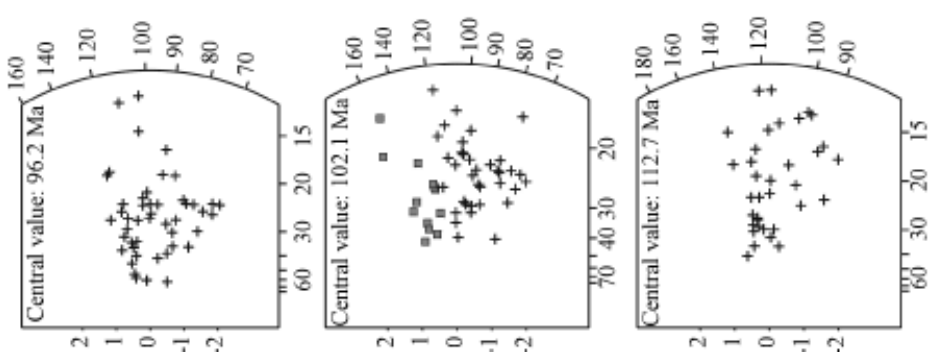

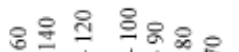
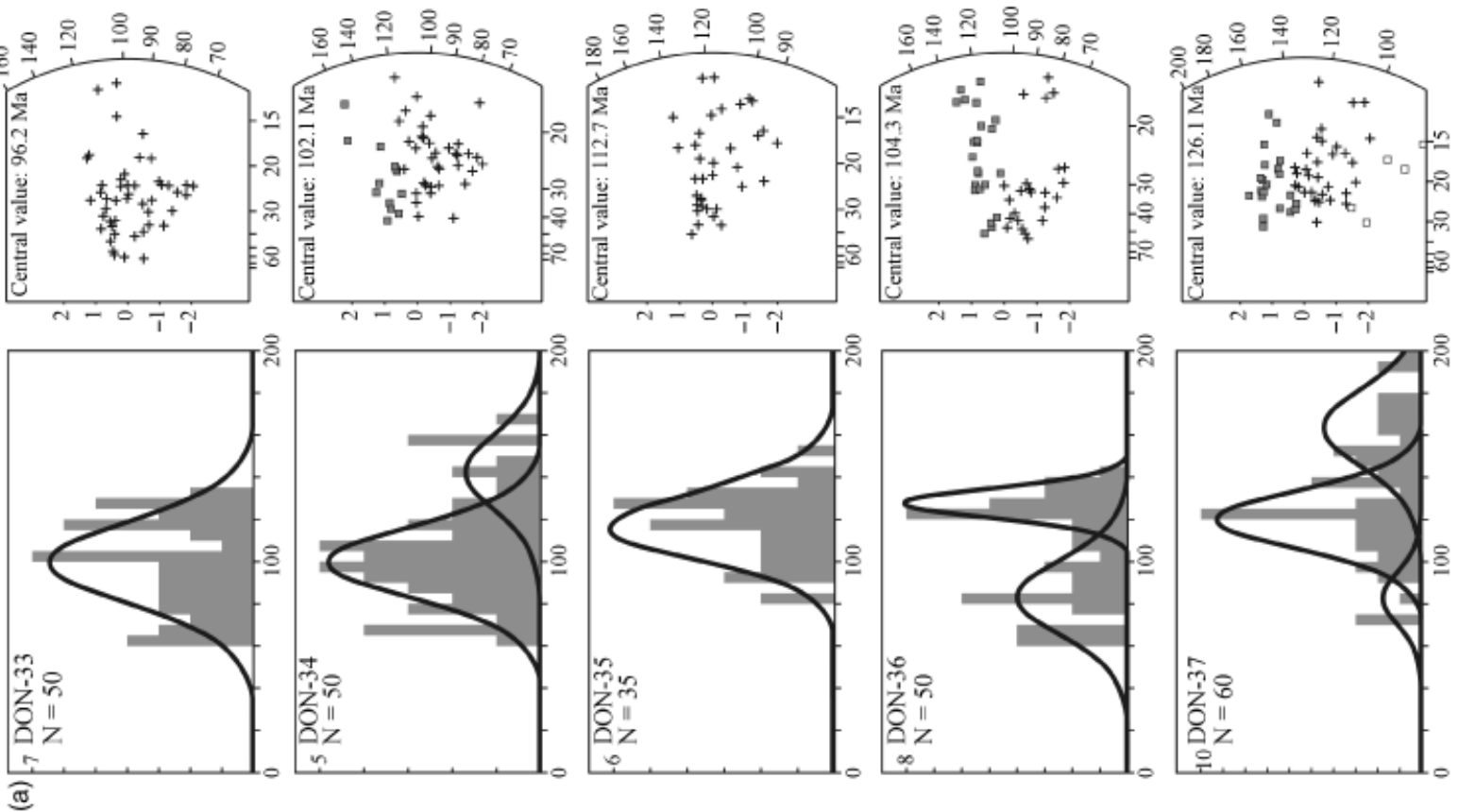

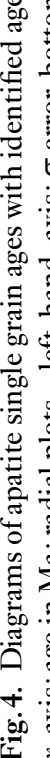

C 2009 The Authors 

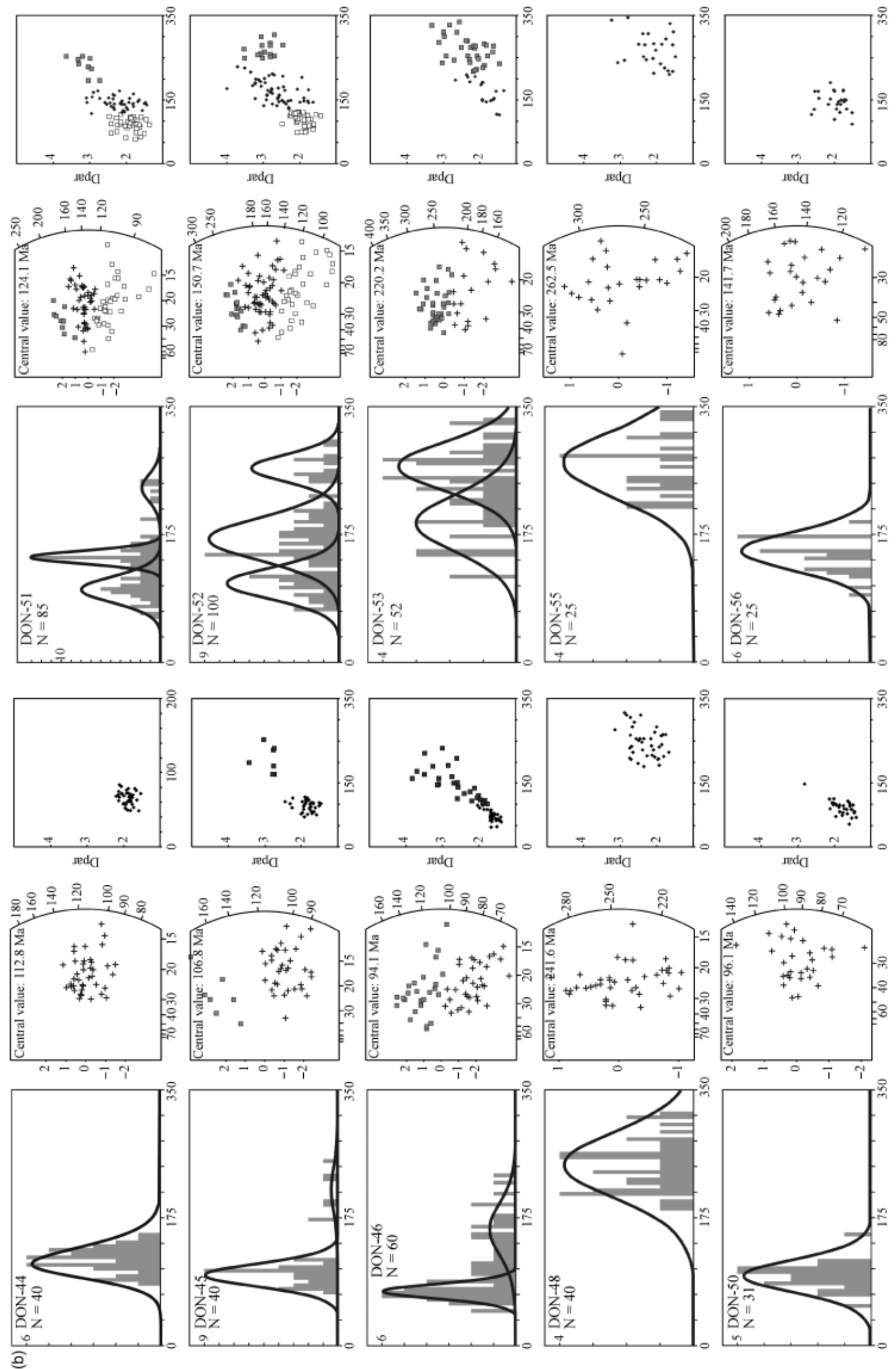

(C) 2009 The Authors

Journal Compilation (C) Blackwell Publishing Ltd, European Association of Geoscientists \& Engineers and International Association of Sedimentologists 
(high dispersion), covering the time span from Carboniferous to Early Palaeocene (Fig. 4). Component analysis of these samples revealed several distinct age populations, including Permian $(\sim 269 \mathrm{Ma})$ to Late Cretaceous ( 74 Ma; Table 3, Figs 4 and 5) clusters.

Mean track lengths (MTL) and standard deviations (SD) in identified age populations cluster between 11.4 and $13.8 \mu \mathrm{m}$ and between 1.2 and $2.1 \mu \mathrm{m}$, respectively, suggesting a thermal history with long stay in the apatite PAZ (APAZ) for all samples (Table 3, see also supporting Fig. S1).

As indicated by the broad range of $D_{\text {par }}$ values $(\sim 1.4$ $4.0 \mu \mathrm{m}$; Fig. 4), the majority of the samples contain a diverse spectrum of apatites in terms of their annealing kinetics. A positive correlation between single grain ages and $D_{\text {par }}$ values can be seen in most of the plots (Fig. 4). This is in line with the annealing concept of kinetically variable apatites (see 'Samples and methods') and facilitates the interpretation.

In both, borehole MS 598/99 and the Severnaya mine, the age of the youngest AFTage population increases with increasing elevation (Fig. 6), although sample Don-50 appears to be slightly younger than one would expect from the trend. Since this sample has the smallest $D_{\text {par }}$ among all samples in the borehole (Table 3), the slightly younger age can be attributed to the lowest resistance to annealing. Nevertheless, the positive age-elevation relationship observed among age populations cannot be straightforwardly used to calculate exhumation rates. This is because correlated age populations (i) are kinetically different as inferred from $D_{\text {par }}$ values (Table 3 ), and do not meet the requirement of 'identical annealing properties' and (ii) do not represent cooling ages as inferred from track length data with significantly shortened tracks.

\section{INTERPRETATION AND DISCUSSION}

In the following sections, we first interpret the data in terms of the chronological succession of the identified thermal events and discuss their contribution to thermal evolution models, which have been proposed for the DF. Then we discuss other tectonic implications and try to constrain time and amount of erosion, as well as the age of basin inversion and formation of the MA.

\section{Thermal evolution}

In order to visualize differences in cooling style between different parts of the DF, we reconstructed the thermal trajectories of some representative samples (Fig. 7). The initial and final points of the trajectories are based on Carboniferous surface temperatures and present day temperatures, respectively. Temperatures reached during maximum Permian burial and/or Permo-Triassic reheating due to magmatic activity (e.g. Krasnoarmeisk area) are estimated using VR of nearby coal seams and thermal histories of adjacent deep wells, which have been calibrated with VR data (for details see Sachsenhofer et al., 2002; Panova et al., 2005). The cooling paths are constrained by the respective PAZs and the presence of AFTage populations (this study and Spiegel et al., 2004). We would like to emphasize that (i) this reconstruction of thermal history is schematic, (ii) the reconstruction is not derived from inverse modelling based on the track length data and (iii) that the reconstructed thermal trajectories are speculative outside the thermal maximum (well constrained by VR data) and outside the PAZs, where the sensitivity of the FT method ends.

\section{The oldest AFT memory: Permian cooling and regional Permo-} Triassic thermal event

The earliest thermal activities in the DF recorded by the AFT thermochronometer are of (i) Permian and (ii) Permo-Triassic age, as indicated by age populations of $\sim 265$ and $\sim 240 \mathrm{Ma}$, respectively. These populations are in some cases comprised of apatites with large $D_{\text {par }}$ values $(>3 \mu \mathrm{m}$; Fig. 4) that are obviously more resistant to annealing. For these apatites, we assume slightly higher temperature sensitivity and conclude that they record cooling below $\sim 130-140^{\circ} \mathrm{C}$. Although these two age groups are very close, they can be separated with respect to their position. Thus we interpret them differently:

(i) Permian AFT ages are obtained along the northern boundary of the DF (Don-55) and in borehole MS 598/99 at a depth of $1220 \mathrm{~m}$ below surface (Don-52). In general, they are recorded by samples with low thermal maturity ( $\leq 1.0 \% R_{\mathrm{r}}$; see Fig. 2), indicating a relatively shallow position $(\leq 3 \mathrm{~km})$ during maximum burial in Permian time. Permian ages were also reported from two sites near the southern border of the DF (Yuzhno Donbassky region, SW Donetsk; Spiegel et al., 2004; see Fig. 2 for position of samples). We interpret these ages to reflect cooling related to Permian exhumation.

(ii) The Permo-Triassic ages are also restricted to samples with thermal maturity $<1.0 \% R_{\mathrm{r}}$ (Fig. 2). They were determined in relatively shallow samples from borehole MS 598/99 (Don-48, Don-51), and also in samples from the Krasnoarmeisk Monocline (Spiegel et al., 2004) and the Azov Massif (Danišík et al., 2008; see Fig. 2 for position of samples). This age group is usually interpreted to record the cooling related to the termination of a Permo-Triassic high heat flow event. This thermal event was first recognized by Sachsenhofer et al. (2002) on the basis of modelling results of VR data and its regional character was confirmed by FT data of Spiegel et al. (2004) and Danišík et al. (2008). These authors showed that maximum temperatures exceeded $\sim 120^{\circ} \mathrm{C}$ (Krasnoarmeisk Monocline, Azov Massif) and locally even $\sim 240^{\circ} \mathrm{C}$ (South Syncline east of Donetsk), as indicated by the total reset of the AFT and ZFT thermochronometers, respectively (Spiegel et al., 2004; Danišík et al., 2008). Furthermore, Sachsenhofer et al. (2002) speculated that in the South Syncline, the Permo-Triassic thermal event might be induced by intrusions of large pluto- 


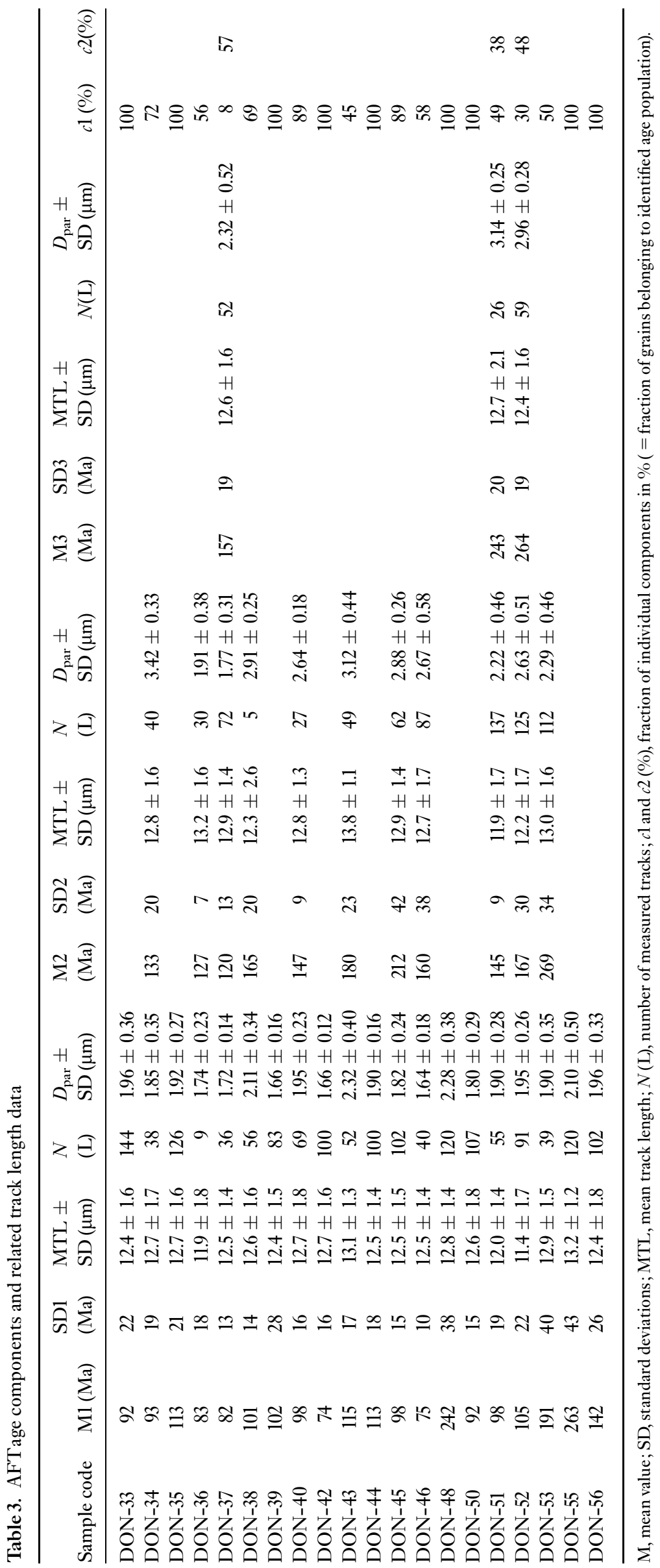




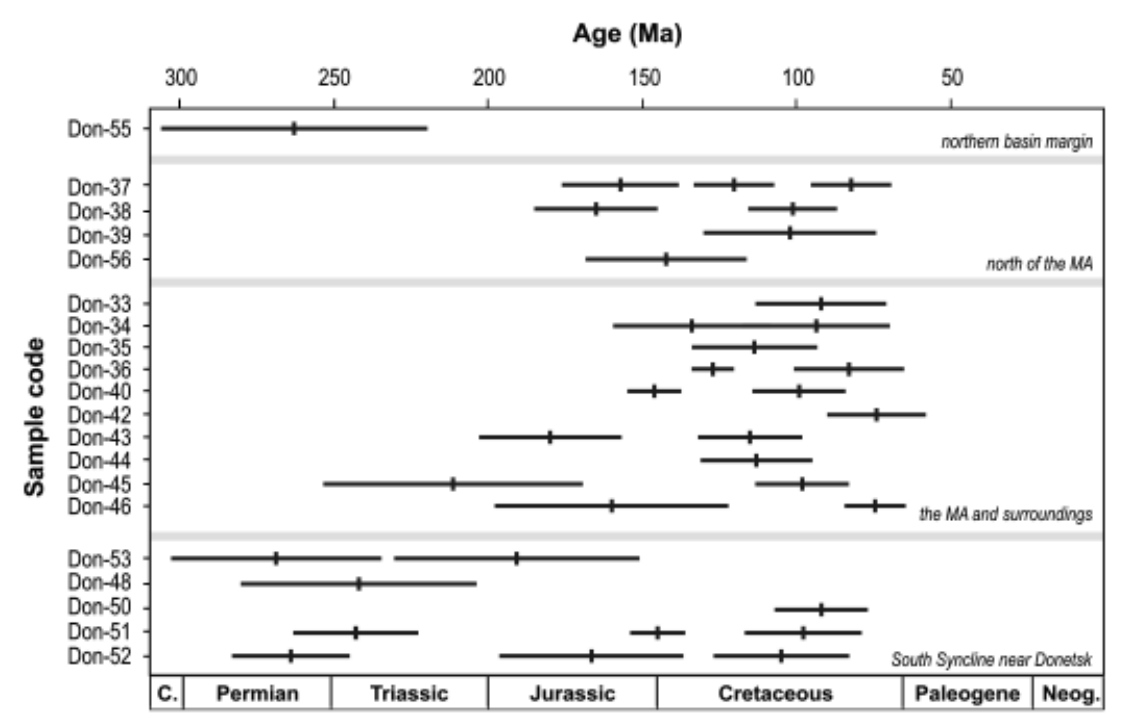

Fig. 5. Diagram of age populations (mean values $\pm \mathrm{SD}$ ) identified by the SIMPLEX procedure (Dantzig, 1998) using PopShare program (Dunkl \& Székely, 2003). The samples are arranged according to their geographical position.

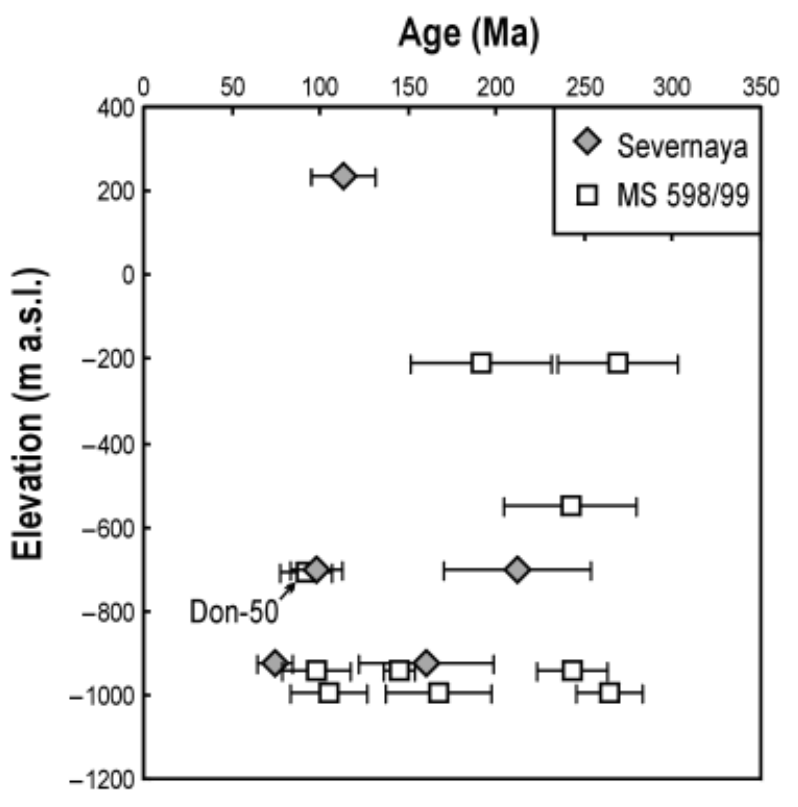

Fig. 6. Age vs. elevation plot of samples from the borehole MS 598/99 and Severnaya mine, where positive correlation between age populations and elevation can be seen.

nic bodies in the Late Permian as postulated by Aleksandrov et al. (1996).

\section{Middle to Late Triassic - thermal inactivity}

Alexandre et al. (2004) used Ar-Ar data (on amphibole, biotite and plagioclase) from intrusions to show that the southern margin of the DF was affected by magmatic activity during Middle to Late Triassic times. The magmatic activity was confirmed by AFT dating of the same intrusions at the southern margin of the DF (Danišík et al., 2008). There is, however, no indication of Triassic thermal activity (cooling or reheating) recorded by the samples in this study. Thus, we conclude that the Middle-Late Triassic magmatic activity had only a local influence and did not alter the regional thermal regime in the DF.

\section{Furassic - slow cooling or thermal stagnation, but no reheating}

The North Anticline (Don-37, Don-38), North Syncline (Don-56), westernmost part of the MA (Severnaya Mine; Don-46) and the southern limb of the MA (Don-43;Figs 2 and 5) displayed the oldest populations of Early to Late Jurassic and earliest Cretaceous age ( 180-140 Ma). Jurassic aged samples were also found in borehole MS 598/ 99 (Don-52, Don-53). From the generally short MTL's, we assume that the samples resided within the APAZ during the Jurassic and cooled slowly. The earliest the samples could have cooled through the APAZ was in the late Early to Late Cretaceous. This is because the majority of samples with Jurassic age components also show age components of Cretaceous age, which is discussed in the next section.

Jurassic AFT ages were also reported from the South Syncline east of Donetsk (Spiegel et al., 2004) and from the southern margin of the DF near Komsomolskoje (Danišík et al., 2008; see Fig. 2 for position of samples). The meaning of these ages is uncertain. Spiegel et al. (2004) used FT thermal models and showed that these ages can be explained either (i) by a very slow, single-stage cooling through the APAZ during most of the Jurassic and parts of the Cretaceous, leaving the APAZ during the Cretaceous (115-84 Ma), or (ii) by a multistage thermal evolution, involving cooling to temperatures $\leq 60{ }^{\circ} \mathrm{C}$ in the Early Jurassic, reheating to $\sim 100{ }^{\circ} \mathrm{C}$ during the Late Jurassic to Early Cretaceous, and a final cooling below $60{ }^{\circ} \mathrm{C}$ in the Cretaceous. Although Spiegel et al. (2004) admit that it is not possible to resolve the thermal history, the second scenario has been favoured by the authors. This is mainly because of the presence of Upper Jurassic magmatic veins in the southwestern DF. However, (i) the magmatic event ( $\sim 155 \mathrm{Ma}$; Lazarenko et al., 1975; Alexandre et al., 2004) postdates the AFT ages of several samples, and (ii) there are no indications of Jurassic magmatic activity in the Komsomolskoje area, and along and north of the MA, where Jurassic age populations occur. Thus, we favour the first solution and propose that Jurassic age 
Fig. 7. Simplified thermal evolution of some representative samples inferred from vitrinite reflectance (VR) and fission track (FT) data indicating differences in cooling style between different parts of the Donbas Foldbelt (DF). The schematic thermal trajectories are either based on the data presented in this study or adopted from Spiegel et al. (2004) and Danišík et al. (2008). Major tectonic, magmatic and thermal events are shown (Privalov, 1998; Stovba \& Stephenson, 1999; Sachsenhofer et al., 2002; Alexandre et al., 2004; Spiegel et al., 2004).

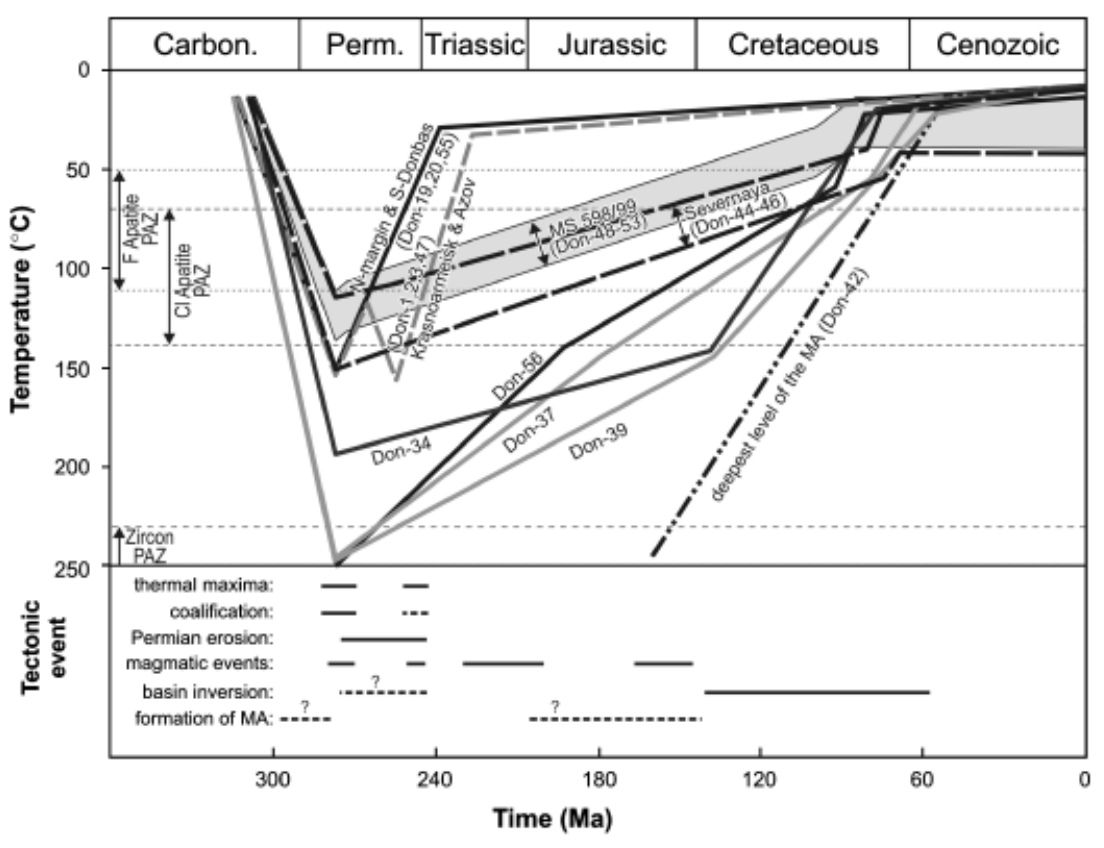

populations are the result of extremely slow cooling and/ or thermal stagnation of the samples within the APAZ lasting at least for most of the Jurassic and until the Cretaceous period.

\section{Cretaceous - final cooling}

The vast majority of the samples (excluding those from the northern and southern basin margins) are of Cretaceous age (Figs 2 and 5, Table 3). These results show that (i) the Cretaceous was the main cooling period in the central parts of DFand that (ii) perhaps apart from the earliest Palaeogene, the investigated parts of the DF were at temperatures below $\sim 60{ }^{\circ} \mathrm{C}$ for the entire Cainozoic period.

Upper Cretaceous (Turonian to Maastrichtian) sediments occur near the northern, western and southern basin margins and partly cover Carboniferous rocks. Lower Cretaceous rocks are present only SW of Donetsk. There is no evidence of magmatic or other events that could have changed the thermal regime. Therefore, Early Cretaceous ages are interpreted to reflect slow cooling or thermal stagnation within the APAZ related to slow exhumation. Final cooling and exhumation of the DF is recorded by the Late Cretaceous ages that slightly predate the erosional unconformity at the Cretaceous/Palaeogene boundary.

Cretaceous AFTages have not been recognized before, although by careful analysis of radial plots of the samples from the folds east of Donetsk (Fig. 5a in Spiegel et al., 2004) one can identify several grains of Early Cretaceous age. This result was not noted, however, presumably due to the small number of counted apatite grains. Nevertheless, Spiegel et al. (2004) argued for Cretaceous cooling (i.e. cooling trajectories crossing the $60{ }^{\circ} \mathrm{C}$ isotherm between 140 and $80 \mathrm{Ma}$ ) as inferred from thermal modelling and the age-elevation relations, which argued for a preCretaceous age for folding.
The impact of the new thermochronological data on this and other geodynamic issues are elaborated in the next section.

\section{Tectonic implications}

\section{Timing and amount of erosion}

Although the total thickness of eroded rocks in the DF could be reasonably reconstructed from coalification data from deep wells together with numeric models (e.g. Sachsenhofer et al., 2002), the timing of erosion has not yet been constrained. Nevertheless, it is generally believed that the largest portion of rock was eroded during Late Permian times (e.g. Sachsenhofer et al., 2002; Alsaab et al., 2008) and that post-Permian erosion was negligible. The new FT data, which are a powerful tool in this respect, show a more complex picture, and in combination with coalification data allow us to refine the erosional history of the area. According to the AFTand coalification patterns, the study area can be separated into two domains, each with distinct thermal evolution (Fig. 2).

(a) Domain I (Fig. 2) covers the western margin of the DF along the Donetsk-Kadievka fault zone, Krasnoarmeisk Monocline and the Azov Massif. Characteristic features of this domain are (i) low thermal maturity $\left(<1.2 \% R_{\mathrm{r}}\right)$, (ii) Permian and Permo-Triassic AFTages, and (iii) proximity of Mesozoic (including Lower/Middle Triassic) rocks that unconformably overlie Permo-Carboniferous successions.

The Permian and Permo-Triassic AFTages in all samples of this domain indicate that total (Permian and post-Permian) erosion was $\sim 2.5-3 \mathrm{~km}$ (assuming a surface temperature of $10^{\circ} \mathrm{C}$, a closure temperature $\sim 130^{\circ} \mathrm{C}$ and a geothermal gradient of $40-50^{\circ} \mathrm{C} \mathrm{km}^{-1}$ for the PermoTriassic high heat flow event). The erosion values are in good agreement with conclusions of Sachsenhofer et al. (2002) and Alsaab et al. (2008) who estimated an erosion of 
1.5-2.5 km based on VR data and numeric modelling results.

Timing of erosional episodes in this part can be constrained as follows: Samples from the marginal parts of the DF [i.e. Yuzhno-Donbassky region (Spiegel et al., 2004) and sample Don-55 from the northern basin boundary near Lisitchansk] yielded Permian AFTages and lack any younger age component. This indicates a major Permian erosional event followed by a time of thermal stability. A similar scenario applies to the Krasnoarmeisk Monocline and the Azov Massif, where thermal stability since Triassic times was documented by Permo-Triassic AFT and apatite (U-Th)/He ages (Spiegel et al., 2004; Danišík et al., 2008).

Samples from the western margin of the DF (Donetsk area; west of the Donetsk-Kadievka fault zone) are situated close to the Mesozoic rocks, suggesting that postPermian erosion was minor and that most of the erosion occurred during pre-Mesozoic times. However, several samples from this area contain not only the Permo-Triassic but also Jurassic and Cretaceous age populations (Figs 2 and 5). This shows that significant erosion must have occurred in the Mesozoic period.

(b) Domain II includes the major part of the DF east of the Donetsk-Kadievka fault zone and also includes Devonian rocks exposed at the southern basin margin near Komsomolskoje, which yield Jurassic AFT ages (Danišík et al., 2008). It is characterized by (i) higher thermal maturity $\left(>2.5 \% R_{\mathrm{r}}\right.$ ), (ii) younger (Jurassic and Late Cretaceous) AFTages, regardless of annealing properties and (iii) the complete absence of Triassic to Lower Cretaceous strata.

According to the AFT data an erosional event must have occurred in the Mesozoic, and its magnitude was definitely more than $\sim 4 \mathrm{~km}$ (assuming a closure temperature of $\sim 130^{\circ} \mathrm{C}$ for chlorine rich apatites, a geothermal gradient $30^{\circ} \mathrm{C} \mathrm{km}^{-1}$ and a surface temperature of $10^{\circ} \mathrm{C}$ ). Moreover, important information on the erosional history in the central DF is provided by the ZFTage of sample Don-42, which is located in the axis of the MA in the structurally lowest position. Assuming the ZFT age of $159 \pm 10 \mathrm{Ma}$ is a cooling age, the sample cooled through the zircon PAZ during the Middle to Late Jurassic. The implication is that at this location, erosion of $\sim 7.5 \mathrm{~km}$ of material has occurred since Late Jurassic times (assuming a closure temperature of $\sim 240^{\circ} \mathrm{C}$, a geothermal gradient $30^{\circ} \mathrm{C} \mathrm{km}^{-1}$, and a surface temperature of $10^{\circ} \mathrm{C}$ ). Total erosion (i.e. Permian+ post-Permian) in this area was probably in the order of $10-12 \mathrm{~km}$ as inferred from coal rank data (Nagorny \& Nagorny, 1976). If this estimate is correct, our observations imply that more than $60 \%$ of erosion occurred since Jurassic times. This figure likely represents the maximum value and is related to the formation of the Main Anticline (MA, see 'next section'). Apart from the MA, however, the total erosion in this domain did not exceed $\sim 7.5 \mathrm{~km}$ as inferred from Carboniferous ZFTages reported by Spiegel et al. (2004) (samples Don-17, 18, see Fig. 2 for location).

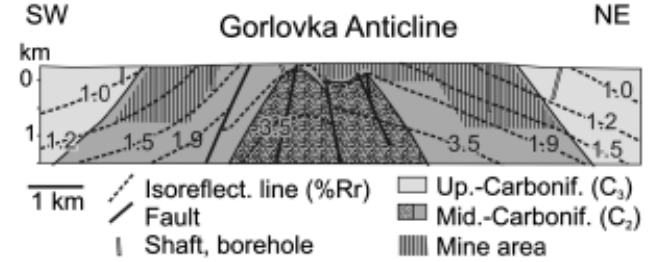

Fig. 8. Cross-section through the Main Anticline, trace of the profile is indicated in Fig. 2. The position of vitrinite isoflectance lines is constrained by data from coal seams in the mines and from boreholes (modified after Levenshtein et al., 1991; Sachsenhofer et al., 2002).

\section{Timing of folding and formation of the $M A$}

As mentioned in 'Geological setting', the age of the main structures is not clear. Here, we discuss the age of the MA in the light of FT data.

Coalification in the DF occurred during Permian maximum burial in the Sakmarian ( $\sim 275 \mathrm{Ma}$; e.g. Sachsenhofer et al., 2002; Izart et al., 2003; Alsaab et al., 2008) or during the Permo-Triassic thermal event (Sachsenhofer et al., 2002). The observed oblique relationship between VR isolines and bedding planes along the MA (see Fig. 8) shows that the MA was already partly formed before coalification. The inclination of the isoreflectance lines further indicates a post-Permian accentuation of the structure.

All samples taken from the profile across the MA (Don43 - southern limb of the MA, Don-33 - crest, Don-35, Don-40 - northern limb, Don-34 - North Syncline, Don-37-39 - North Anticline) revealed a fairly loose cluster of Cretaceous ages, showing no correlation with structural position. Therefore, we conclude that the formation of the MA was completed before Cretaceous times. This agrees with Spiegel et al. (2004), who argued for a pre-Cretaceous main folding episode based on AFT data from the area south of the MA.

Information on the formation of the westernmost part of the MA is provided by samples Don-44-46 from the Severnaya mine. These samples are from similar stratigraphic levels (Moscovian), but different present-day depths ranging from $0 \mathrm{~m}$ (Don-44) to $1160 \mathrm{~m}$ below surface (Don-46; Fig. 9). The observed positive correlation between Cretaceous AFT ages and present-day elevation is another argument for mainly pre-Late Cretaceous folding.

Whereas Late Cretaceous AFT age populations are widespread in the western and central DF (east of the Donetsk-Kadievka fault zone), Early Cretaceous to Jurassic single grain ages were determined in sample Don-56 (Bashkirian) located east of Krasnij Luch in the North Syncline. This suggests earlier uplift of this part of the basin.

\section{Inversion of the $D F$}

As mentioned in 'Geological setting', the age of inversion of the DF is another disputed issue. It is not clear whether the inversion occurred in the Permian (e.g. Popov, 1936, 1939, 1963; Gavrish, 1989; Milanovsky, 1992; Privalov, 1998) 


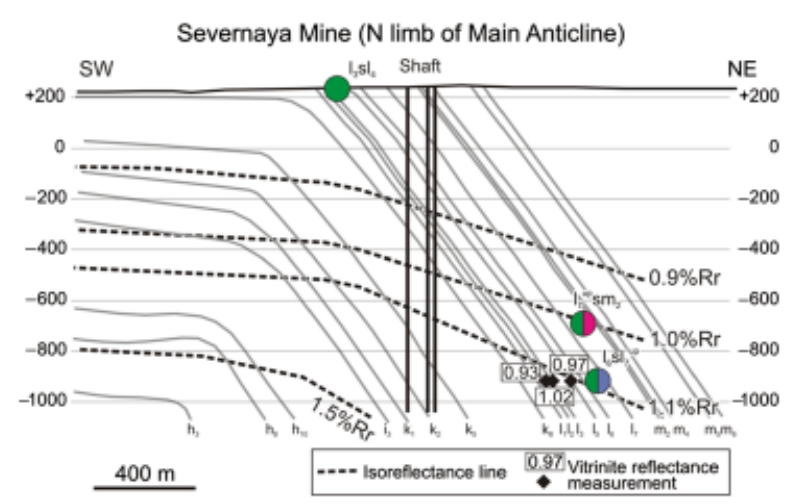

Fig. 9. Cross-section through the Severnaya Mine located in the northern limb of the Main Anticline. The position of fission track (for colour-coding see Fig. 2) and vitrinite reflectance (VR) samples is displayed.VR isolines are shown schematically using information of boreholes located a few hundred metres aside the profile.

or later, specifically during the Cretaceous/Palaeocene boundary deformation phase (e.g. Stovba $\&$ Stephenson, 1999; Saintot et al., 2003a, b). According to the AFT data from the central part of the basin, where inversion and pop-up should be most pronounced, the major phase of cooling and erosion occurred throughout the Cretaceous. Therefore, we conclude that the DF inverted and poppedup at that time. The youngest detected AFT age populations coincide (within error) with the Cretaceous/ Palaeogene boundary and reflect that the final cooling of the DF was probably related to the deformation event at that time as postulated by Stovba \& Stephenson (1999) and Saintot et al. (2003a, b). Since then, the DF has been thermally inactive.

Relationship between the geodynamic setting of the southern
margin of Europe and the thermotectonic history of the DF

The present-day knowledge of the relationship between the geodynamic processes affecting the southern margin of Europe and the evolution of the DF have been summarized by Saintot et al. (2006). These authors emphasize that northward directed subduction of the Palaeotethys beneath the southern margin of eastern Europe became increasingly oblique during the Carboniferous, eventually evolving into a dominantly transcurrent Permian plate boundary. Based on this model, Saintot et al. (2006) speculate that shearing resulted in the detachment and breakoff of the subducted slab. Thus, the significant Permian uplift of the southern margin of the East-European Platform, including the DF and the Azov Massif, may have resulted from slab break-off. Permian and Permo-Triassic magmatism may be another result of slab break-off. FT data record both exhumation induced cooling ( $\sim 265 \mathrm{Ma}$ ) and cooling following the Permo-Triassic magmatic event ( 240 Ma).

The formation of the MA started before maximum burial of the Permo-Carboniferous basin fill and, therefore, during a time characterized by basin-wide subsi- dence. This supports a salt-induced formation (e.g. related to transtension) rather than a compression-related origin. The new FT data suggest that further accentuation of the MA occurred before the Cretaceous. Therefore, we speculate that it is related to a compression event at the Late Triassic/Early Jurassic boundary (e.g. Popov, 1963; Privalov, 1998; Saintot et al., 2003a), which is linked to the (Eo-)Cimmerian accretion from Iran to Europe (Saintot et al., 2006).

Middle to Late Jurassic magmatic activity is an important feature in the evolution of the DF and the Azov Massif, but is not recorded elsewhere in the southeastern part of Europe (Saintot et al., 2006). Therefore, it is regarded as a local phenomenon. Following the discussion in 'Jurassic - slow cooling or thermal stagnation, but no reheating', the magmatic activity is unlikely to have reheated the sediments. In contrast, the FT data suggest slow cooling or thermal stagnation.

\section{CONCLUSIONS}

The new FT data provide important constraints on the thermotectonic evolution of the Ukrainian DF. The most significant results are summarized as follows:

- Upper Carboniferous sediments of the DF record a wide range of AFT ages, covering a span between the Late Permian $(\sim 265 \mathrm{Ma})$ and Late Cretaceous ( $\sim 70 \mathrm{Ma}$ ). This shows that the FTapproach provides valuable information on the thermal history during a 200-Myr long period of basin evolution, which followed maximum burial ( $\sim 275 \mathrm{Ma}$ );

- The earliest thermal activity of Permian and PermoTriassic age is recorded by the samples located on the basin margins and west of Kadievka-Donetsk fault zone. Permian ages are interpreted to reflect cooling related to exhumation, whereas the Permo-Triassic ages record a thermal event related to mantle upwelling associated with increased heat flow and local magmatic activity;

- Samples from the central parts of the DF, east of the Kadievka-Donetsk fault zone were residing or slowly cooling through the APAZ during Jurassic and most of Cretaceous times, and then finally cooled to nearsurface conditions latest around the Cretaceous/Palaeogene boundary;

- Permian erosion was of lesser, and Mesozoic erosion of greater importance than generally assumed. A Jurassic ZFT age from the crest of the MA shows that in this region more than $60 \%$ of total erosion occurred in the Mesozoic;

- The MA started to form before coalification in the Permian and a second pulse of folding occurred before Cretaceous times;

- Inversion and pop-up of the DF occurred in the Cretaceous and not in the Permian as previously thought. This is indicated by overall Cretaceous AFTages in the central parts of the basin. 


\section{ACKNOWLEDGEMENTS}

This study was funded by the German Science Foundation (DFG, Project number SP 673/3-1). R. F. S. acknowledges support from a MOEL+scholarship of the 'Österreichische Forschungsgemeinschaft'. Sampling was supported by V.A. Antsiferov and A.V. Antsiferov (UkrNIMI, Donetsk). Gerlinde Höckh, Dorothea Mühlbayer-Renner and Dagmar Kost (Tübingen) are thanked for careful sample preparation. An earlier version of the manuscript benefited from constructive reviews by Charlotte Cederbom (GFZ, Potsdam), Aline Saintot (NGU, Trondheim), Peter van der Beek (Joseph Fourier University, Grenoble) and two anonymous reviewers. English language was improved by Noreen Evans (CSIRO, Exploration and Mining and John de Laeter Centre of Mass Spectrometry, Perth).

\section{REFERENCES}

Aleksandrov, A.L., Gordienko, V.V., Derevskaya, K.I., Zemskov, G.A., Ivanov, A.P., Panov, B.S., Shumlyanskiy, V.A. \& Epov, O.G. (1996) Deep structure, evolution of fluid systems and endogenic gold-bearing potentiality, South-Eastern part of Ukrainian Donets Basin (in Russian). Edition of Institute of Fundamental Researches of Ukrainian Scientific Association, Kyiv, $74 \mathrm{pp}$.

Alexandre, P., Chalot-Prat, F., Saintot, A., Wijbrans, J., Stephenson, R., Wilson, M., Kitchka, A. \& Stovba, S. (2004) $\mathrm{The}{ }^{40} \mathrm{Ar} /{ }^{39} \mathrm{Ar}$ dating of magmatic activity in the Donbas Fold Belt and the Scythian Platform (Eastern European Craton). Tectonics, 23, TC5002.

Alsaab, D., Elie, M., Izart, A., Sachsenhofer, R.F. \& PrivaLOV, V.A. (2008) Predicting methane accumulations generated from humic Carboniferous coals in the Donbas Foldbelt (Ukraine). AAPG Bull., 92/8, 1029-1053.

Barbarand, J., Carter, A., Hurford, T. \& Wood, I. (2003) Compositional and structural control of fission-track annealing in apatite. Chem. Geol., 198, 107-137.

Belichenko, P.V., Gintov, O.B., Gordienko, VV., Korchemagin, V.A., Panov, B.S., Pavlov, I.A. \& Usenko, O.V. (1999) Main stages of Olkhovatsko-Volyntsevskaya Anticline evolution in Donbas in connection with its ore potential according to tectonophysical, geothermal and gravimetric data (in Russian). Geophys. F., 21/2, 69-84.

BeLoKon, V.G. (1971) Geological history of evolution of the Donbas (in Russian). Geology and Prospecting of Coal Deposits. Nedra, Moscow, pp. 3-15.

BeLokon, V.G. (1975) Deep structure of the Donbas (in Russian). Geol. 7., 5, 11-27.

Bogdanov, A.A., Obruchev, D.V., Puscharovskiy, Y.M. \& Trusova, I.F. (1947) Materials About the Geology of the Devonian Deposits in the Southern Margin of the Donets Basin. Izvestiya MOIP, Moscow, 61pp.

Borodulin, M.I. (1974) New approach of regional seismic investigations techniques and geological referencing of interfaces in the Dniepr basin (in Russian). Geophys. Collect., 60, 9-17.

Brandon, M.T., Roden-Tice, M.K. \& Garver, J.I. (1998) Late Cenozoic exhumation of the Cascadia accretionary wedge in the Olympic Mountains, NW Washington State. GSA Bull., 110/8, 985-1009.

Burtner, R.L., Nigrini, A. \& Donelick, R.A. (1994) Thermochronology of Lower Cretaceous source rocks in the IdahoWyoming thrust belt. AAPG Bull., 78/10, 1613-1636.

Carlson, W.D., Donelick, R.A. \& Kecham, R.A. (1999) Variability of apatite fission-track annealing kinetics: I. Experimental results. Am. Mineral., 84, 1213-1223.

Chekunov, A.V., Kaluzhnaya, L.T. \& Ryabchun, L.I. (1993) The Dniepr-Donets paleorift, Ukraine, deep structures and hydrocarbon accumulations. F. Pet. Geol., 16, 183-196.

Chenunov, A.V. \& Naumenko, V.V. (1982) Relationship between the Earth's crust's deep rearrangement, tectonic movements, magmatism, metamorphism and metal content in the Dnieper-Donets Paleorift. Geophys. 7., 4, 25-34.

Cooper, M.A. \& Williams, G.D. (1989) Inversion tectonics. Geol. Soc. Lond. Spec. Publ., 44, 375 pp.

Danišík, M., Kuhlemann, J., Dunkl, I., Székely, B. \& Frisch, W. (2007) Burial and exhumation of Corsica (France) in the light of fission track data. Tectonics, 26, TC1001, doi: 10.1029/2005TC001938, 1-24.

Danišík, M., Sachsenhofer, R.F., Privalov, V.A., Panova, E.A., Frisch, W. \& Spiegel, C. (2008) Low-temperature thermal evolution of the Azov Massif (Ukrainian Shield - Ukraine) - implications for interpreting (U-Th)/He and fission track ages from cratons. Tectonophysics, 456, 171-179.

Dantzig, G.B. (1998) Linear Programming and Extensions. Princeton Landmarks in Mathematics. Princeton University Press, Princeton, 648pp.

De Boorder, H., van Beek, A.J.J., Dijkstra, A.H., Galetsky, L.S., Koldewe, G. \& Panov, B.S. (1996) Crustal architecture of the Donets Basin, tectonic implications for diamond and mercury-antimony mineralisation. Tectonophysics, 268, 293309.

Dobrefraction'99 Working Group: Grad, M., Gryn, D., Guterch, A., Janik, T., Keller, R., Lang, R., Lyngsie, S.B., Omelchenko, V., Starostenko, V.I., Stephenson, R.A., Stovba, S.M., Thy bo, H. \& Tolkunov, A. (2003) "DoBREFRACTION'99" - velocity model of the crust and upper mantle beneath the Donbas Foldbelt (East Ukraine). Tectonophysics, 371, 81-110.

Donelick, R.A., Ketcham, R.A. \& Carlson, W.D. (1999) Variability of apatite fission-track annealing kinetics: II. Crystallographic orientation effects. Am. Mineral., 84/9, 1224-1234.

Dumitru, T.A. (1993) A new computer-automated microscope stage system for fission-track analysis. Nucl. Tracks Radiat. Meas., 21, 575-580.

DUNKL, I. (2002) TRACKKEY: a Windows program for calculation and graphical presentation of fission track data. Comput. Geosci., 28/2, 3-12.

DunkL, I. \& SzékelY, B. (2003) Component analysis with visualization of fitting - PopShare, a freeware program for evaluation of mixed geochronological data. Geophys. Res. Abstr., 5, 02657.

EisenVERG, D.E. (1988) Geology and Oil and Gas Occurrences of the Dniepr-Donets Depression: Stratigraphy (in Russian). Naukova Dumka, Kiev, 148pp.

Eisenverg, D.E., Babenko, A.M., Belenko, N.G., Belokon, N.G., Bragin, Y.N., Dedov, V.S., Fissunenko, O.P., Getman, V.G., Konashov, V.G., Lagutina, V.V., Levenshtein, M.L., Makarov, I.A., Nagorny, Y.N., Nesterenko, L.P., Poletaev, V.I., Popov, V.S., Rotai, P.P., Sharmanova, G.V., Shohegolev, A.K. \& Sokolova, G.U. (1975) Field excursion 
guidebook for Donets basin. In: International Congress on Carboniferous Stratigraphy and Geology, VIIIth, Field Trip Guidebook. Nauka, Moscow, , 360pp.

Galbraith, R.F. \& Laslett, G.M. (1993) Statistical models for mixed fission track ages. Nucl. Tracks Radiat. Meas., 21, 459-470.

Garkalenko, I.A., Borodulin, M.I. \& Mikhalev, A.K. (1971) About the transition zone between the Dniepr-Donets Basin and Donets Folded Structure (in Russian). Geol. 7., 314, 92-98.

Gavrish, V.K., (Ed.) (1989) Geology and Oil and Gas Potential of the Dniepr-Donets Depression: Depth Structure and Geotectonic Evolution (in Russian). . Naukova Dumka, Kiev, 208pp.

GLEadow, A.J.W. (1981) Fission track dating methods: What are the real alternatives? Nucl. Tracks Radiat. Meas., 5, 3-14.

Gleadow, A.J.W., Duddy, I.R. \& Green, P.F. (1986a) Fission track lengths in the apatite annealing zone and the interpretation of mixed ages. EPSL, 78, 245-254.

Gleadow, A.J.W., Duddy, I.R. \& Green, P.F. (1986b) Confined fission track lengths in apatite: A diagnostic tool for thermal history analysis. Contrib. Mineral. Petrol., 94, 405-415.

Gleadow, A.J.W., Duddy, I.R. \& Lovering, K.A. (1983) Fission track analysis: a new tool for the evaluation of thermal histories and hydrocarbon potential. Petrol. Explor. Assoc. Aust. 7., 23, 93-102.

GordienKo, V.V., Zavgorodnyaya, OV. \& Usenko, O.V. (1999) The heat flow of the Donets Basin. Geophys. F., 19, 209-214.

Green, P.F., Duddy, I.R., Gleadow, A.J.W., Tingate, P.R. \& LASLETt, G.M. (1986) Thermal annealing of fission tracks in apatite, 1. A qualitative description. Chem. Geol. (Isotope Geoscience Section), 59, 237-253.

Green, P.F., Duddy, I.R., Laslett, G.M., Hegarty, K.A., Gleadow, A.J.W. \& Lovering, J.R. (1989) Thermal annealing of fission tracks in apatite. 4. Quantitative modeling techniques and extension to geological timescales. Chem. Geol., 79, 155-182.

Hurford, A.J. (1986) Cooling and uplift patterns in the Lepontine Alps, South Central Switzerland and an age of vertical movement on the Insubric fault line. Contrib. Mineral. Petrol., 92, 413-427.

Hurford, A.J. \& Green, P.F. (1983) The zeta age calibration of fission-track dating. Chem. Geol., 41, 285-312.

ILChenko, T.V. (1996) Dniepr-Donets Rift: deep structure and evolution from DSS profiling. Tectonophysics, 268, 83-98.

Izart, A., Le Nindre, Y., StePhenson, R., Vaslet, D. \& StovвA, S. (2003) Quantification of the control of sequences by tectonics and eustacy in the Dniepr-Donets Basin and on the Russian Platform during Carboniferous and Permian. Bull. Soc. Géol. Fr., 174, 93-100.

Ketcham, R.A., Carter, A., Donelick, R.A., Barbarand, J. $\&$ Hurford, A.J. (2007a) Improved measurement of fissiontrack annealing in apatite using c-axis projection. Am. Mineral., 92, 789-798.

Ketcham, R.A., Carter, A., Donelick, R.A., Barbarand, J. \& HuRFord, A.J. (2007b) Improved modeling of fission-track annealing in apatite. Am. Mineral., 92, 799-810.

Kolosovska, V.A., Marakhovska, I.I., Demekhin, L.O., Metalidi, G.M., Sydorova, D.A. \& Solovytsky, V.M. (2007) Geological Map Pre-Cenozoic Formations of Ukraine. Scale 1:1 000 000. State Geological Service of Ukraine, Ukraine.

Konashov, V.C. (1980) Expression of an Early Cimerian folding phase in the Donets Basin (in Russian). Geotectonics, 4, 29-36.

Kusznir, N.J., Stovba, S.M., Stephenson, R.A. \& Poplavskit, K.N. (1996) The formation of the northwestern Dniepr-
Donets Basin: 2D forward and reverse syn-rift and post-rift modelling. In: EUROPROBE: Intraplate Tectonics and Basin Dynamics of the Eastern European Platform (Ed. by R.A. Stephenson, M. Wilson, H. de Boorder \& V.I. Starostenko), Tectonophysics, 268, 237-255.

KUŤKO, A.G. (1995) Geologic map of Pre-Cenozoic sediments (territory of Donbbassgeologiya). Scale 1:200,000. Goskomgeologiya, Donbassgeologiya, Artemovsk.

LaZarenko, E.K., Panov, B.S. \& Gruba, V.I. (1975) The Mineralogy of the Donets Basin, 1 (in Russian). Naukova dumka, Kiev, $225 \mathrm{pp}$.

Levenshtein, M.L., Spirina, O.I., Nosova, K.B. \& Dedov, V.S. (1991) Map of Coal Metamorphism in the Donetsk Basin (Paleozoic surface). 1:500 000. Ministry of Geology of the USSR, Kiev.

Lyashkevich, Z.M. (1987) Magmatism of the Pripyat-Dnieper-Donets Paleorift (in Russian). Naukova Dumka, Kiev, 176pp.

Maidanovich, I.A. \& Radzivill, A.YA. (1984) Specific Features of Coal Basins in Ukraine (in Russian). Naukova Dumka, Kiev, $120 \mathrm{pp}$.

Maystrenko, Yu., Stovba, S., Stephenson, R., Bayer, U., Menyoli, E., Gajewski, D., Huebscher, C., Rabbel, W., Saintot, A., Starostenko, V., Thybo, H. \& Tolkunov, A. (2003) Crustal-scale pop-up structure in cratonic lithosphere: DOBRE deep seismic reflection study of the Donbas Foldbelt, Ukraine. Geology, 31, 733-736.

McCann, T., Saintot, A., Chalot-Prat, F., Kitchka, A., Fokin, P. \& Alekseev, A. \& Europrobe-Intas Research Team (2003) Evolution of the southern margin of the Donbas (Ukraine) from Devonian to Early Carboniferous times. In: Tracing Tectonic Deformation Using the Sedimentary Record (Ed. by T. McCann \& A. Saintot), Geol. Soc. Lond., Spec. Publ., 208, 117135.

Milanovsky, E.E. (1987) Geology of the USSR Vol. I (in Russian). Moscow University Press, 416pp.

Milanovsky, E.E. (1992) Aulacogens and aulacogeosynclines: regularities in setting and evolution. In: Geodynamics of Rifting, Vol. III. Thematic Discussions (Ed. by P.A. Ziegler), Tectonophysics, 215, 55-68.

Nagorny, Yu.N. \& Nagorny, V.N. (1976) Peculiarities of geological evolution of the Donets Basin (in Russian). Geotectonica, 1, $74-86$.

Nesterenko, L.P. (1978) Early Permian Deposits of the KalmiusTorets Depression in the Donets Basin (in Russian). Vischa shkola, Kiev, 148pp.

Nikolskiy, J.L., Buturlinov, N.V., Panov, B.S. \& KorcemaGIN, V.A. (1973) Beitrag zur Metallogenie des Donezbeckens (UdSSR). Z. Angem. Geol., 19/10, 505-508.

Panova, E.A., Privalov, V.A., Sachsenhofer, R.F. \& AntsiFEROV, V.A. (2005) Exploration strategy in the Donets Basin (Ukraine): Definitions from thermal and burial history reconstruction. 67th EAGE Conference \& Exhibition, Extended Abstract, P237.

Pogrebnov, N.I. (1971) History of tectonic movements and sedimentation in the eastern part of the Great Donbas (in Russian). In: Geology and Prospecting of Coal Deposits. Nedra, Moscow, 15-24.

Popov,V.S. (1936) New data on the tectonics of the northern marginal part of the Donets Basin (in Russian). Probl. Sov. Geol., 12, 1025-1043.

Popov, V.S. (1939) The tectonics of the Donets Basin (in Russian). Report of the 17th International Geological Congress, USSR. 
Popov, V.S. (1963) Tectonics of the Donets basin (in Russian). Geology of Coal and Oil Shale Deposits of the USSR, vol. 1, Nedra, Moscow, 103-151.

Privalov, V.A. (1998) Block rotations and scenario of the tectonic evolution of the Donets Basin (in Russian). Geol. Geochem. Fossil Fuel Deposits, 4, 142-158.

Privalov, V.A., Sachsenhofer, R.F., Panova, E.A. \& AntsiFEROV, V.A. (2004) Coal geology of the Donets Basin (Ukraine/ Russia): an overview. Berg. Monatshefte, 149, 212-222.

Privalov, V.A., Zhykalyak, M.V., Piskovoy, M.A. \& Panova, E.A. (2000) Structural setting and principal displacement zone of the Donets Basin. EUROPROBE Workshop, Gurzuf, 12-16 October 2000. Geophys. 7., 4/22, 119-120.

Rahn, M.K., Brandon, M.T., Batt, G.E. \& Garver, J.I. (2004) A zero-damage model for fission-track annealing in zircon. Am. Mineral., 89/4, 473-484.

Sachsenhofer, R.F., Privalov, V.A., Zhykalyak, M.V., BueKer, C., Panova, E.A., Rainer, T., Shymanovskyy, V.A. \& StePhenson, R.A. (2002) The Donets Basin (Ukraine/Russia): coalification and thermal history. Int. 7. Coal Geol., 49, $33-55$.

Saintot, A., Stephenson, R., Brem, A., Stovba, S. \& PrivaLOV, V. (2003a) Palaeostress field reconstruction and revised tectonic history of the Donbas fold-and-thrust belt (Ukraine and Russia). Tectonics, 22, 1059 doi: 10.1029/2002TC001366.

Saintot, A., Stephenson, R., Stovba, S. \& Maystrenko, Y. (2003b) Structures associated with inversion of the Donbas Foldbelt. Tectonophysics, 373, 181-207.

Saintot, A., Stephenson, R.A., Stovba, S.M., Brunet, M.F., Yegorova, T. \& Starostenko, V. (2006) The evolution of the southern margin of Eastern Europe (Eastern European and Scythian platforms) from the latest Precambrian-Early Paleozoic to the Early Cretaceous. In: European Lithosphere Dynamics (Ed. by D.G. Gee \& R.A. Stephenson), Geol. Soc. Lond., Mem., 32, 481-505.

Sobel, E.R., Seward, D., Ruiz, G., Kounov, A., Ege, H., Wipf, M. \& KRUGH, C. (2004) Influence of etching conditions on Dpar measurements: Implications for thermal modeling. Paper presented at International Conference on Fission Track and Thermochronology, Free University, Amsterdam, Netherlands, 8-14 August.

Spiegel, C., Sachsenhofer, R.F., Privalov, V.A., Zhykalyak, M.V. \& Panova, E.A. (2004) Thermotectonic evolution of the Ukrainian Donbas Foldbelt: evidence from zircon and apatite fission track data. Tectonophysics, 383, 193-215.

Stepanov, P.I. (1937) Southern excursion, Donets Carboniferous Basin (in Russian). In: 17th International Geological Congress, Moscom (Ed. by P.I. Stepanov) ONTI NKTP USSR, 114pp.

Stephenson, R.A. \& The Europrobe Intraplate Tectonics And Basin Dynamics Working Group (1993) Continental rift development in Precambrian and Phanerozoic Europe: EURoProBE and the Dniepr-Donets rift and Polish Trough basins. Sediment. Geol., 86, 159-175.

Stephenson, R.A., Stovba, S.M. \& Starostenko, V.I. (2001) Pripyat-Dniepr-Donets Basin: Implications for dynamics of rifting and the tectonic history of the northern Peri-Tethyan platform. In: Peri-Tethyan Rift/Wrench Basins and Passive Margins, Peri-Tethys Memoir 6 (Ed. by P.A. Ziegler, W. Cavazza, A.H.F. Robertson \& S. Crasquin-Soleau), Mém. Mus. Natl. Hist. Nature., 186, 369-406.

Stephenson, R.A., Yegorova, T., Brunet, M.-F., Stovba, S., Wilson, M., Starostenko, V., Saintot, A. \& Kusznir, N.
(2006) Late Paleozoic intra- and pericratonic basins on the East European Craton and its margins. In: European Lithosphere Dynamics (Ed. by D.G. Gee \& R.A. Stephenson), Geol. Soc. Lond. Mem., 32, 463-479.

Stovba, S.M. \& Stephenson, R.A. (1999) The Donbas Foldbelt: its relationships with the uninverted Donets segment of the Dniepr-Donets Basin, Ukraine. Tectonophysics, $313,59-83$.

Stovba, S.M., Stephenson, R.A. \& Kivshik, M. (1996) Structural features and evolution of the Dniepr-Donets Basin, Ukraine, from regional seismic reflection profiles. Tectonophysics, 268, 127-147.

TAgami, T. (2005) Zircon fission-track thermochronology and applications to fault studies. Rev. Mineral. Geochem., 58, 95-122.

Tagami, T. \& Shimada, C. (1996) Natural long-term annealing of the zircon fission track system around a granitic pluton. 7 . Geophys. Res., 101, 8245-8255.

UstinovskiY, Y.B. (1955) Conditions of sedimentation of the Devonian deposits on the southern margins of the Donets Basin (in Russian). Geol. Z., 15, 30-42.

WAGNER, G.A. (1968) Fission track dating of apatites. EPSL, 4, 411-415.

Wagner, G.A. \& Van den haute, P. (1992) Fission-Track Dating. Enke Verlag, Stuttgart, Germany, 285pp.

Wilson, M. \& LyashKevich, Z. (1996) Magmatism and the geodynamics of rifting in the Pripyat-Dniepr-Donets rift, East European Platform. In: EUROPROBE: Intraplate Tectonics and Basin Dynamics of the Eastern European Platform (Ed. by R.A. Stephenson, M. Wilson, H. de Boorder \& V.I. Starostenko), Tectonophysics, 268, 65-81.

Zaun, P. \& Wagner, G.A. (1985) Fission track stability in zircon under geological conditions. Nucl. Tracks Radiat. Meas., 10, 303-307.

\section{Supporting Information}

Additional Supporting Information may be found in the online version of this article:

Figure S1. (a) Confined track length distributions of measured samples (total number of measured horizontal confined tracks); (b) Confined track length distributions of identified age populations. Explanation of histograms: $\mathrm{y}$-axis: number of tracks; $\mathrm{x}$-axis: length in $\mu \mathrm{m}$; text from the top: sample code; mean track length \pm standard deviation (both in $\mu \mathrm{m}$ ); number of measured tracks.

\section{Table S1. Coordinates of the samples.}

Please note: Wiley-Blackwell are not responsible for the content or functionality of any supporting materials supplied by the authors. Any queries (other than missing material) should be directed to the corresponding author for the article.

Manuscript received 23 Fuly 2008; Manuscript accepted 17 August 2009 